\title{
BEHAVIOUR OF HIGH-STRENGTH CONCRETE CIRCULAR COLUMNS CONFINED BY HIGH-STRENGTH SPIRALS UNDER CONCENTRIC COMPRESSION
}

\author{
Chongchi HOU ${ }^{1,2,3}$, Wenzhong ZHENG ${ }^{1,2,3^{*}}$, Wei CHANG ${ }^{1,2,3}$ \\ ${ }^{1}$ School of Civil Engineering, Harbin Institute of Technology, Harbin, China \\ ${ }^{2}$ Key Lab of Structures Dynamic Behavior and Control of the Ministry of Education, Harbin Institute of \\ Technology, Harbin, China \\ ${ }^{3}$ Key Lab of Smart Prevention and Mitigation of Civil Engineering Disasters of the Ministry of Industry and \\ Information Technology, Harbin Institute of Technology, Harbin, China
}

Received 15 June 2019; accepted 6 January 2020

\begin{abstract}
This paper tested the behaviour of 32 high-strength concrete columns confined by high-strength spirals under concentric compression. The test parameters included unconfined concrete compressive strength, spiral yield strength, volumetric ratio, and spiral spacing. The results showed that bulging and shear sliding were the two characteristic types of failure patterns of the thirty-two confined columns, depending on spiral spacing and concrete strength. Moreover, the spiral in most specimens did not yield at the confined concrete compressive strength. An analytical confinement model for high-strength concrete columns confined by high-strength spirals was proposed. In this proposed model, the calculated value of the spiral stress at the confined concrete compressive strength was used to calculate the feature points of the stressstrain curve. The proposed model showed good correlations with available experimental results of 64 columns.
\end{abstract}

Keywords: high-strength, confined concrete, circular column, spiral strain, stress-strain curve.

\section{Introduction}

High-strength concrete (HSC) is widely used in the construction industry, particularly in high-rise and large-span buildings. Using HSC in columns can effectively reduce column size because of the high load-carrying capacity per unit weight of HSC. The reduction in column size results spacious buildings and bridges. Moreover, the high density of HSC leads to beneficial effects for sustainable development (Ramezanianpour, 2014). High-strength concrete columns confined by conventional stirrups can increase concrete compressive strength and peak strain at the maximum strength of confined concrete to a certain extent (Han et al., 2003). However, normal-strength stirrups provide low confinement pressure for HSC columns, and consequently, the high compressive strength of HSC may not be completely developed. On the contrary, highstrength stirrups not only allow complete development of the high compressive strength of HSC, but also reduce the number of stirrups required. Moreover, HSC columns confined by high-strength stirrups, show good deformability (Paultre et al., 2001). Currently, several interna- tional design codes recommend the use of high-strength steel bars as stirrups. Presently, high-strength steel bars are widely used in practice. The ACI 318-19 code permits the use of high-strength steel bars with the maximum yield strength of $690 \mathrm{MPa}$ as spirals in design (American Concrete Institute [ACI], 2019). Grade $800 \mathrm{MPa}$ steel bars are also recommended for use as stirrups in practice in NZS 3101 (Standard Association of New Zealand, 2006). Deformed steel bars with yield strength of $785 \mathrm{MPa}$ are commercially available in Taiwan for use as stirrups (Ou \& Kurniawan, 2015a, 2015b).

Recently, valuable experimental research efforts have focused on the behaviour of HSC columns confined by high-strength steel bars under concentric (Taheri et al., 2017; Razvi \& Shaikh, 2018; Eid et al., 2018; Campione \& Minafò, 2010; Bing et al., 2001; Foster \& Attard, 2008; Issa \& Toban, 1994; Cusson \& Paultre, 1994; Afifi et al., 2014, 2015; Wang et al., 2017; Li et al., 2018) and eccentric loadings (Liao et al., 2017; Hadi \& Zhao, 2011; Kim et al., 2017b). Yong et al. (1988) tested 24 confined con-

*Corresponding author. E-mail: zhengwenzhonghit@163.com 
crete columns, with concrete compressive strength ranging from 83.6 $\mathrm{MPa}$ to $93.5 \mathrm{MPa}$ and stirrup yield strength of $500 \mathrm{MPa}$, subjected to concentric compression. He reported that the volumetric ratio $\left(\rho_{\mathrm{v}}=V_{\mathrm{sh}} / s A_{\text {cor }}\right)$ affected the behaviour of the confined columns under concentric compression. As the volumetric ratio increased, the compressive strength of the confined concrete columns and peak strain increased. Based on the tests on 20 short circular high-strength confined columns with concrete compressive strength ranging from $60 \mathrm{MPa}$ to $124 \mathrm{MPa}$ and spiral yield strength ranging from $400 \mathrm{MPa}$ to $1000 \mathrm{MPa}$ under concentric compression, Razvi (1995), Razvi and Saatcioglu (1999a) concluded that the high lateral pressure required to confine HSC columns can be provided either by increasing the volumetric ratio or the grade of spiral. They reported that the ratio $\rho_{\mathrm{v}} f_{\mathrm{yv}} / f_{\mathrm{c}}$ was a suitable design parameter for confinement of circular HSC columns. In summary, studies avaliable on the behaviour of highstrength confined concrete circular columns with spiral yield strength higher than $700 \mathrm{MPa}$ are limited.

Several confinement models have been proposed for high-strength confined concrete columns under concentric compression (Razvi \& Saatcioglu, 1999a, 1999b; Akiyama et al., 2010; Legeron \& Paultre, 2003; Hong et al., 2006; Baduge et al., 2018; Kim et al., 2016, 2017a). Razvi and Saatcioglu (1999b) proposed a confinement model for confined concrete based on the test results of 40 circular and rectangular specimens with unconfined concrete compressive strength ranging from $51 \mathrm{MPa}$ to $105 \mathrm{MPa}$ and stirrup yield strength ranging from $400 \mathrm{MPa}$ to $1000 \mathrm{MPa}$. The type of stirrup, volumetric ratio, arrangement of stirrup, concrete strength and section geometry were the factors considered in this model. Akiyama et al. (2010) developed a formalised stress-average strain model based on an analysis of the test results of 27 confined concrete columns with unconfined concrete compressive strength raning from $44 \mathrm{MPa}$ to $120 \mathrm{MPa}$ and stirrup yield strength ranging from $1395 \mathrm{MPa}$ to $1480 \mathrm{MPa}$. Effective confinement pressure and compressive fracture energy were used in this model. The above mentioned confinement models and current design codes EN 1992-1-1:2004 (European Committee for Standardization [CEN], 2004), CEB-FIB Bulletin 66 (The International Federation for Structural Concrete [FIB], 2010), CSA A23.3-04 (Canadian Standards Association [CSA], 2004), and GB50010-2010 (China Architecture \& Building Press, 2011) assume that the stirrup yield at compressive strength of confined concrete is accurate for concrete columns confined by normalstrength stirrups. However, the effect of confinement is overestimated based on this assumption, particularly for HSC columns confined by high-strength stirrups (Assa et al., 2001a, 2001b; Antonius, 2014) because stirrup stress may lower than stirrup yield strength at confined concrete compressive strength (Zheng et al., 2018). The spatial distribution of stirrup yield strength should be considered in the design of confined concrete columns. The parameters influencing of development of stirrup strain at confined concrete compressive strength should be considered as well. Kim et al. (2017a) evaluated the pure confinement effect of spirals based on experimental results of 75 confined concrete columns with unconfined concrete compressive strength raning from $28 \mathrm{MPa}$ to $100.1 \mathrm{MPa}$ and spiral yield strength ranging from $472 \mathrm{MPa}$ to $1430 \mathrm{MPa}$. All the 75 confined concrete columns were designed to exclude concrete cover and longitudinal reinfrocement. An model using relationship between axial and lateral strain at peak stress of confined concrete was developed to predict the stress-strain relationship of confined concrete. Cusson and Paultre (1995) proposed a confinement model based on the results of tests of 50 high-strength confined columns. In Cusson's model, the process of stirrup stress calculation at confined concrete compressive strength was quite complicated. The process of iterative calculations reduced the calculation efficiency of this model. Therefore, a simple equation of stirrup stress at confined concrete compressive strength and an accuate confinement model is required to predict the stress-strain curves of HSC columns confined by highstrength stirrups.

The aforementioned research works shows that there are presently few experimental and theoretical studies on HSC columns confined by high-strength spirals. In this study, 32 HSC columns confined by high-strength spirals were tested under concentric compression. Based on the experimental results, we studied the influence of unconfined concrete compressive strength, volumetric ratio and spiral yield strength on the stress-strain curve of confined concrete. Besides, an equation of spiral strain at confined concrete compressive strength was established. Finally, a confinement model for HSC columns confined by high-strength spirals was proposed and evaluated by comparing the predicted values with the experimental results of 64 HSC columns confined by high-strength spirals.

\section{Experimental program}

\subsection{Test specimens}

A total of $32 \mathrm{HSC}$ circular columns, each $265 \mathrm{~mm}$ in diameter and $1100 \mathrm{~mm}$ in height, confined by high-strength spirals, were tested under concentric compression. The circular confined concrete columns used four longitudinal reinforcement steel bars with diameter of $10 \mathrm{~mm}$ and yield strength of $480 \mathrm{MPa}$. All the columns were equipped with spirals and the covers of the columns were $10 \mathrm{~mm}$. The three main parameters of confinement were unconfined concrete compressive strength, spiral yield strength and volumetric ratio. There were four different concrete compressive strengths, ranging from 47.09 to $75.64 \mathrm{MPa}$. Two different grades of spiral were used in the test columns: steel of Grade $800 \mathrm{MPa}$ and Grade $970 \mathrm{MPa}$. There are four different volumetric ratios, ranging from $0.9 \%$ to $2.0 \%$. The spiral spacing met the maximum and minimum spacing requirements specified in ACI 318-19 (ACI, 2019). Figure 1 shows the geometry and reinforcement details of the columns under concentric loads, and Table 1 lists 


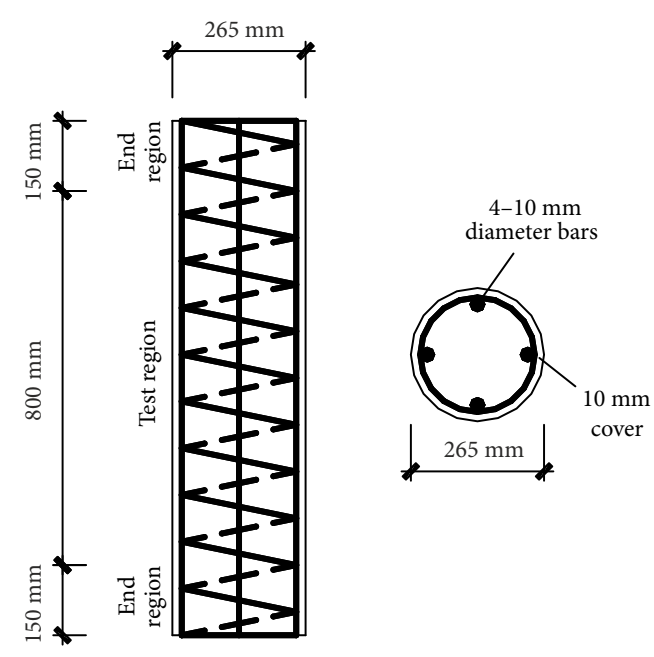

Figure 1. Geometric details of test columns

the complete specifications for each column. Carbon fibre clothes were used around the top and bottom $150 \mathrm{~mm}$ of the columns to prevent sudden damage of the specimens in the end regions, as shown in Figure 2.

\subsection{Material properties}

Each column was constructed using normal-weight, ready-mix concrete. The cube compressive strengths of each batch were determined by testing six $150 \times 150 \times 150$ $\mathrm{mm}$ cubes on the day of testing and then the cube strength was converted to cylinder strength (FIB, 2010). Table 1 lists the cylinder compressive strength $f_{c}$. HRB400 bars were used as longitudinal reinforcements for the columns, while Grade $800 \mathrm{MPa}$ and Grade $970 \mathrm{MPa}$ bars were used as the spirals. Standard tests were carried out, according to ASTM D695-10 (ASTM International, 2010) and ASTM D638-14 (ASTM International, 2014), to determine the mechanical properties of the steel bars. The properties of the longitudinal reinforcements and spirals are given in Table 2.

\subsection{Instrumentation and testing procedures}

Eight reinforcement strain gauges (1-8) were glued to four longitudinal steel bars in the middle section, 270 $\mathrm{mm}$ in length, to measure the longitudinal reinforcement strain. Four reinforcement strain gauges (9-12) were placed on one hoop of spiral to measure spiral strain and four concrete strain gauges (13-16) were pasted onto the surface of concrete cover to measure concrete strain, as shown in Figure 3. The axial deformation of each specimen was recorded by four displacement meters (17-20) located at mid-height on each side of the specimens with gauge length of $270 \mathrm{~mm}$, as shown in Figure 4.

Concentric vertical load was provided by an electrohydraulic servo universal testing machine with a capacity of $10000 \mathrm{kN}$ capacity. The testing machine was stiff enough to measure the descending branch of the loaddeformation curve of each specimen. To ensure concentric loading, a spherical hinge was applied between the testing

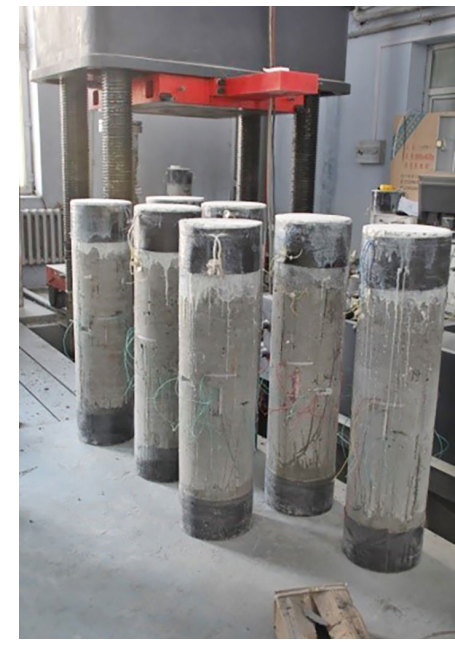

Figure 2. Sample specimens

specimens and the upper plate of the testing machine, as shown in Figure 5. A monotonic concentric compression was applied in two stages. In the first stage, the loading rate was $150 \mathrm{kN} / \mathrm{min}$ until the load reached approximately $70 \%$ of the estimated ultimate bearing capacity. Next, in the second stage, the load was increased at a rate of $0.4 \mathrm{~mm} / \mathrm{min}$ until failure.

\section{Experimental results}

\subsection{Observed behaviour}

All the specimens were damaged at mid of length and behaved in a similar manner until concrete cover cracked. Two types of failure pattern were observed in the specimens: (1) bulging, (2) shear sliding along the failure plane inclined at $40-60^{\circ}$ to horizontal. Figure 6 shows the appearances of specimen ACS-Y-9 and ACS-Y-8 after testing. The failure mechanism of ACS-Y-9 was bulging and that of ACS-Y-8 was shear sliding. The bulging failure pattern was mostly observed in specimens with closely spaced spirals while the shear sliding failure pattern was usually observed in specimens with widely spaced spirals. The failure patterns of the 32 specimens are given in Table 1 .

Specimens with closely spaced spirals, such as ACS-Y-9, exhibited linear elastic stage before the value of load reached $50 \%$ of the maximum. When the load reached approximately $80 \%$ of the maximum, the specimens reached the elastic-plastic stage. During this stage, vertical crack of the concrete cover occurred, increased, and developed. When the compressive load approached the maximum value, the concrete cover spalled, the sound of the fracture splitting was audible, and the spiral was exposed. With the reduction in axial load and spalling of concrete cover, the concrete core was crushed, and the specimens were damaged. The closely spaced spiral provided larger lateral stress on the concrete core, which was in a state of triaxial stress, which enhanced the ultimate capacity and ductility of the specimens effectively. For specimens with widely spaced spirals, such as ACS-Y-8, vertical and inclined crack of the concrete cover occurred in the elastic-plastic stage. 
Table 1. Details of test specimen and summary of test results

\begin{tabular}{|c|c|c|c|c|c|c|c|c|c|c|c|}
\hline $\begin{array}{l}\text { Specimen } \\
\text { number }\end{array}$ & $f_{\mathrm{c}} / \mathrm{MPa}$ & $f_{\mathrm{yv}} / \mathrm{MPa}$ & $d / \mathrm{mm}$ & $s / \mathrm{mm}$ & $\rho_{\mathrm{v}} / \%$ & $f_{\mathrm{cc}} / \mathrm{MPa}$ & $\varepsilon_{\mathrm{cc}} / 10^{-6}$ & $\varepsilon_{0.85} / 10^{-6}$ & $\varepsilon_{\mathrm{sv}} / 10^{-6}$ & $\sigma_{\mathrm{sv}} / \mathrm{MPa}$ & $\begin{array}{l}\text { Failure } \\
\text { pattern }\end{array}$ \\
\hline ACS-Y-1 & 47.09 & 729 & 9 & 50 & 2.0 & 83.51 & 12148 & 13963 & 3825 & 684 & bulging \\
\hline ACS-Y-2 & 47.09 & 729 & 9 & 65 & 1.6 & 74.88 & 9481 & 12667 & 4579 & 704 & bulging \\
\hline ACS-Y-3 & 47.09 & 756 & 7 & 50 & 1.2 & 69.42 & 7111 & 10370 & 5466 & 746 & bulging \\
\hline ACS-Y-4 & 47.09 & 756 & 7 & 70 & 0.9 & 61.76 & 5370 & 9444 & 6423 & 758 & shear sliding \\
\hline ACS-Y-5 & 47.09 & 977 & 9 & 50 & 2.0 & 82.98 & 11482 & 14066 & 3778 & 838 & bulging \\
\hline ACS-Y-6 & 47.09 & 977 & 9 & 65 & 1.6 & 75.37 & 9963 & 12852 & 4648 & 878 & bulging \\
\hline ACS-Y-7 & 47.09 & 985 & 7 & 50 & 1.2 & 70.94 & 7333 & 11778 & 5627 & 932 & bulging \\
\hline ACS-Y-8 & 47.09 & 985 & 7 & 70 & 0.9 & 64.23 & 6667 & 11259 & 7276 & 986 & shear sliding \\
\hline ACS-Y-9 & 59.44 & 729 & 9 & 50 & 2.0 & 95.14 & 10222 & 12444 & 3454 & 675 & bulging \\
\hline ACS-Y-10 & 59.44 & 729 & 9 & 65 & 1.6 & 88.61 & 9370 & 12259 & 4202 & 694 & bulging \\
\hline ACS-Y-11 & 59.44 & 756 & 7 & 50 & 1.2 & 82.59 & 6963 & 9630 & 5053 & 734 & shear sliding \\
\hline ACS-Y-12 & 59.44 & 756 & 7 & 70 & 0.9 & 73.26 & 5185 & 7296 & 6092 & 757 & shear sliding \\
\hline ACS-Y-13 & 59.44 & 977 & 9 & 50 & 2.0 & 97.26 & 9889 & 13259 & 3496 & 825 & bulging \\
\hline ACS-Y-14 & 59.44 & 977 & 9 & 65 & 1.6 & 88.72 & 9333 & 12000 & 4175 & 856 & bulging \\
\hline ACS-Y-15 & 59.44 & 985 & 7 & 50 & 1.2 & 83.14 & 7000 & 10148 & 5175 & 912 & shear sliding \\
\hline ACS-Y-16 & 59.44 & 985 & 7 & 70 & 0.9 & 76.69 & 5778 & 9815 & 6923 & 985 & shear sliding \\
\hline ACS-Y-17 & 68.59 & 729 & 9 & 50 & 2.0 & 100.76 & 8259 & 10407 & 3187 & 668 & bulging \\
\hline ACS-Y-18 & 68.59 & 729 & 9 & 65 & 1.6 & 94.45 & 7185 & 10222 & 3936 & 687 & bulging \\
\hline ACS-Y-19 & 68.59 & 756 & 7 & 50 & 1.2 & 90.54 & 6259 & 9000 & 4709 & 723 & shear sliding \\
\hline ACS-Y-20 & 68.59 & 756 & 7 & 70 & 0.9 & 84.11 & 4704 & 6963 & 5711 & 754 & shear sliding \\
\hline ACS-Y-21 & 68.59 & 977 & 9 & 50 & 2.0 & 101.45 & 8074 & 10111 & 3150 & 809 & bulging \\
\hline ACS-Y-22 & 68.59 & 977 & 9 & 65 & 1.6 & 95.05 & 7259 & 10000 & 3735 & 836 & shear sliding \\
\hline ACS-Y-23 & 68.59 & 985 & 7 & 50 & 1.2 & 89.24 & 6370 & 9852 & 4842 & 897 & shear sliding \\
\hline ACS-Y-24 & 68.59 & 985 & 7 & 70 & 0.9 & 87.18 & 5037 & 7148 & 6163 & 956 & shear sliding \\
\hline ACS-Y-25 & 75.64 & 729 & 9 & 50 & 2.0 & 106.14 & 5889 & 8074 & 2659 & 654 & bulging \\
\hline ACS-Y-26 & 75.64 & 729 & 9 & 65 & 1.6 & 100.49 & 4667 & 7481 & 3318 & 971 & shear sliding \\
\hline ACS-Y-27 & 75.64 & 756 & 7 & 50 & 1.2 & 95.71 & 3630 & 6444 & 4002 & 702 & shear sliding \\
\hline ACS-Y-28 & 75.64 & 756 & 7 & 70 & 0.9 & 90.49 & 3074 & 5222 & 4875 & 728 & shear sliding \\
\hline ACS-Y-29 & 75.64 & 977 & 9 & 50 & 2.0 & 108.62 & 5963 & 8889 & 2723 & 789 & bulging \\
\hline ACS-Y-30 & 75.64 & 977 & 9 & 65 & 1.6 & 101.27 & 4630 & 8000 & 3230 & 813 & shear sliding \\
\hline ACS-Y-31 & 75.64 & 985 & 7 & 50 & 1.2 & 91.65 & 3926 & 6741 & 4111 & 865 & shear sliding \\
\hline ACS-Y-32 & 75.64 & 985 & 7 & 70 & 0.9 & 91.53 & 3259 & 5296 & 4895 & 900 & shear sliding \\
\hline
\end{tabular}

Notes: The nomenclature of columns is as follows: ACS is short for "Axial Compression Specimen", Y means the specimen cross-section is circular.

Table 2. Mechanical properties of longitudinal reinforcements and spirals

\begin{tabular}{|l|c|c|c|c|c|c|c|}
\hline \multirow{2}{*}{ Bar Type } & \multirow{2}{*}{$d_{b} / \mathrm{mm}$} & \multicolumn{3}{|c|}{ Tension } & \multicolumn{3}{c|}{ Compression } \\
\cline { 3 - 7 } & & $f_{\mathrm{y}}\left(f_{\mathrm{yv}}\right) / \mathrm{MPa}$ & $f_{\mathrm{u}} / \mathrm{MPa}$ & $E_{\mathrm{s}} / \mathrm{MPa}$ & $f_{\mathrm{y}}\left(f_{\mathrm{yv}}\right) / \mathrm{MPa}$ & $f_{\mathrm{u}} / \mathrm{MPa}$ & $E_{\mathrm{s}} / \mathrm{MPa}$ \\
\hline HRB400 & 10 & 480 & 640 & $2.00 \times 10^{5}$ & 480 & 640 & $2.00 \times 10^{5}$ \\
\hline Grade $800 \mathrm{MPa}$ & 7 & 756 & 907 & $2.05 \times 10^{5}$ & - & - & - \\
\cline { 2 - 7 } & 9 & 729 & 905 & $2.05 \times 10^{5}$ & - & - & - \\
\hline Grade 970MPa & 7 & 985 & 1153 & $2.05 \times 10^{5}$ & - & - & - \\
\cline { 2 - 7 } & 9 & 977 & 1139 & $2.05 \times 10^{5}$ & - & - \\
\hline
\end{tabular}

Notes: $d_{b}$ is bar diameter; $f_{\mathrm{y}}\left(f_{\mathrm{yv}}\right)$ is yield strength(nominal yield strength); $f_{\mathrm{u}}$ is ultimate strength; and $E_{\mathrm{s}}$ is elasticity modulus. 
a) Distribution of reinforcement strain gauges

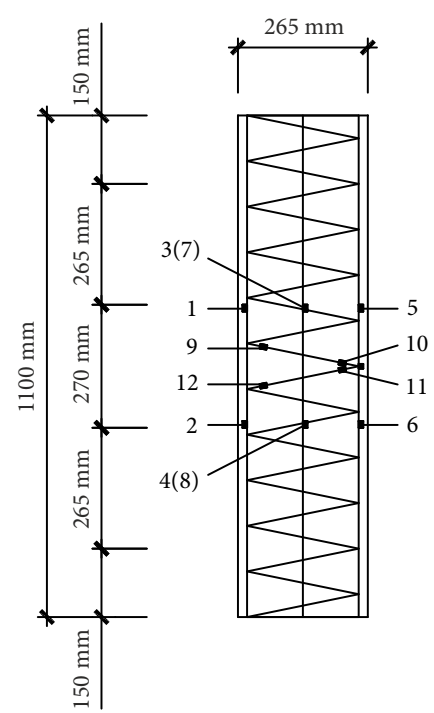

b) Distribution of concrete strain gauges

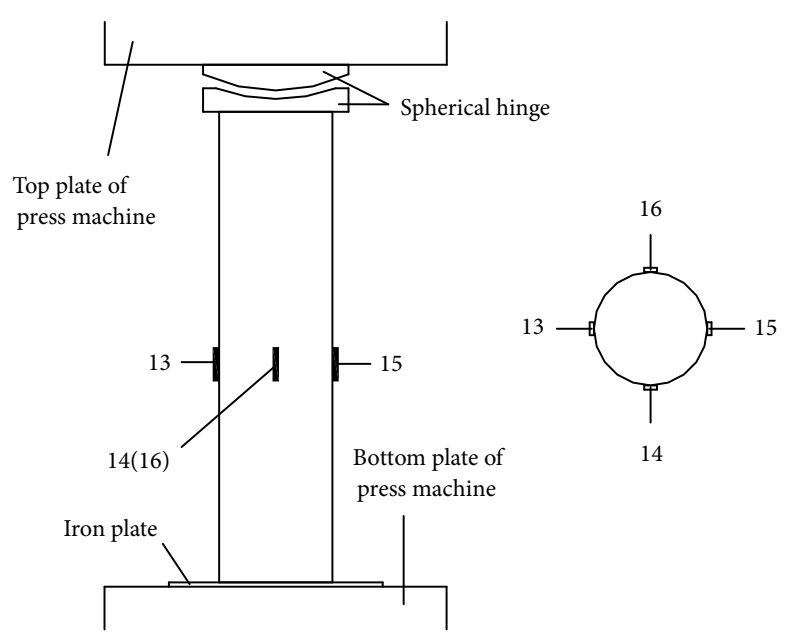

Figure 3. Distribution of strain gauges: a) distribution of reinforcement strain gauges; b) distribution of concrete strain gauges

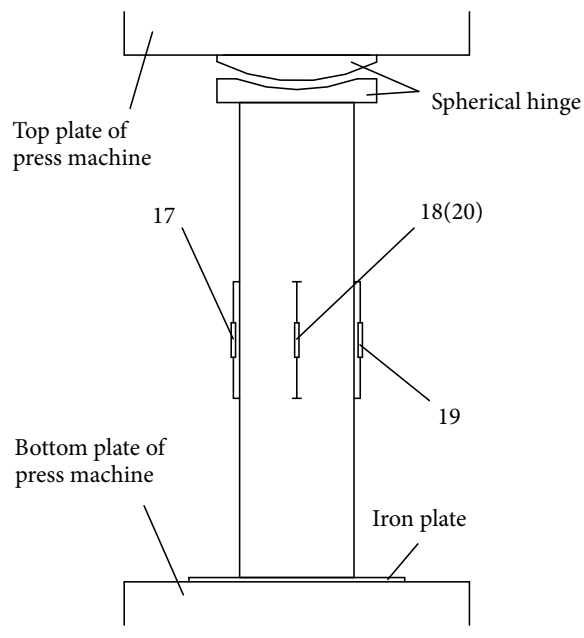

Figure 4. Arrangement of displacement meters

a)

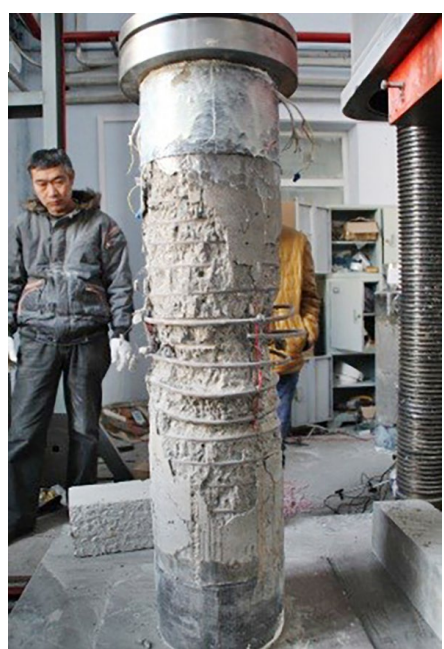

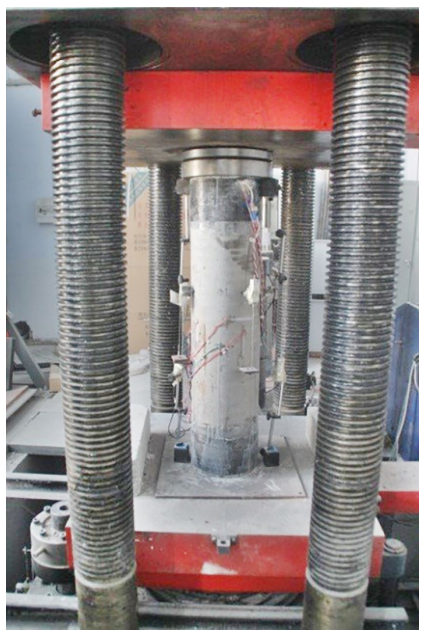

Figure 5. Sample test device

b)

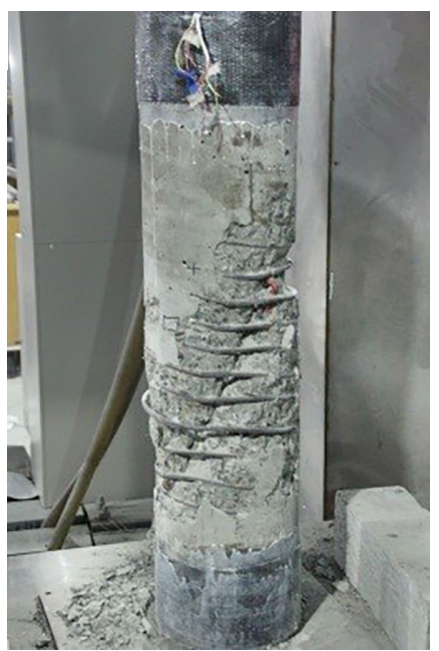

Figure 6. Failure pattern of confined concrete: a) bulging: ACS-Y-9; b) shear sliding: ACS-Y-8 
When the compressive load approached the maximum value, the concrete cover spalled partly and the inclined crack elongated and deepened. With reduction in the axial load, the concrete core around the main inclined crack was crushed and specimens were damaged.

Since the top surface and bottom surface of specimens were not absolutely flat, there was deviation between vertical force on the top surface and vertical center line of specimens. The main tensile stress in the central section may not perpendicular to the vertical center line of specimens. If the volumetric ratio is relatively small and spiral spacing is relatively wide, oblique cracks will appear in the middle-height section of specimen when the main tensile stress reaches unconfined concrete compressive strength. Finally, the failure pattern of the specimen is shear sliding, as shown in Figure 7(b). If the volumetric ratio is relatively large and spiral spacing is relatively close, strong restraint of spiral could limit the occurrence of oblique cracks (Zhang \& Wang, 2004). With the increase of vertical load, vertical cracks appear and develop, then cover concrete plump up and spall. Finally, the failure pattern of the specimen is bulging, as shown in Figure 7(a). Since the ratio of concrete tensile strength to compressive strength and Poisson ratio decrease with the increase of unconfined concrete compressive strength, the higher the unconfined concrete compressive strength is, the more prone to shear sliding.
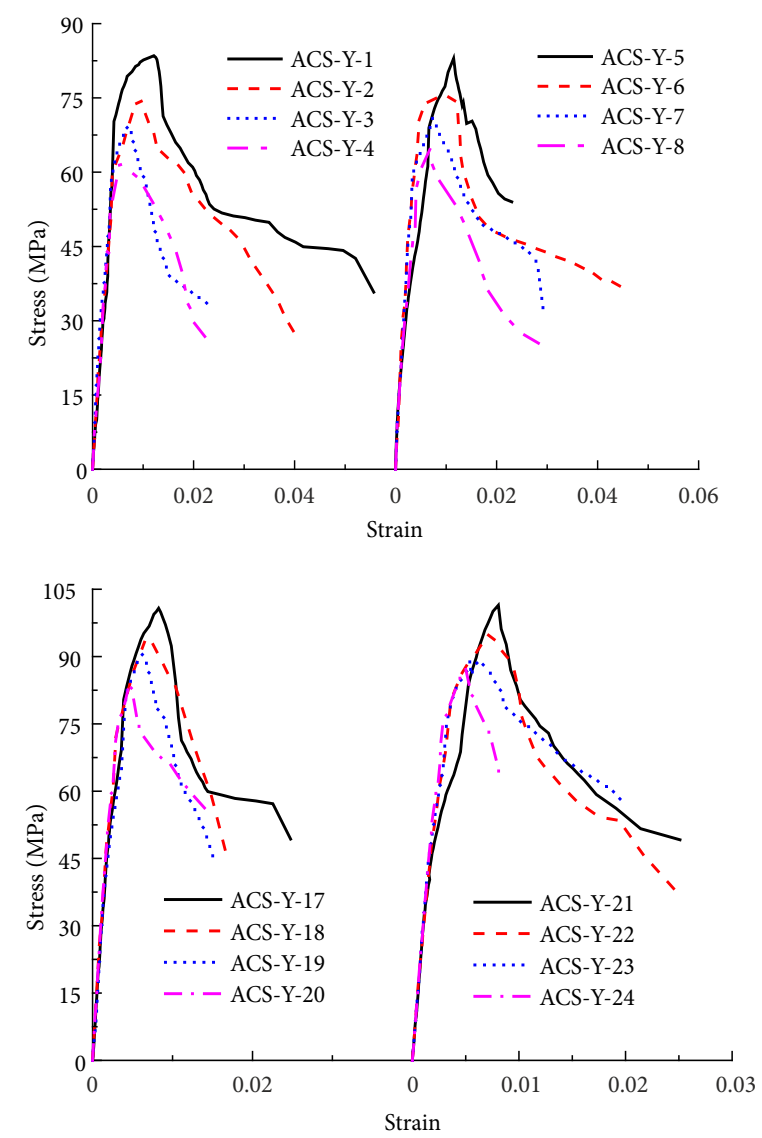

\subsection{Test results}

When unconfined concrete compressive strength was less than $60 \mathrm{MPa}$, the spiral did not yield at maximum axial load with the volumetric ratio of $1.2 \sim 2.0 \%$ but yielded at maximum axial load with the volumetric ratio of $0.9 \%$ (specimens ACS-Y-4, ACS-Y-8, ACS-Y-12, and ACSY-16). The spirals of all columns with unconfined concrete compressive strength ranging from $69 \mathrm{MPa}$ to $76 \mathrm{MPa}$ did not yield at maximum axial load, except for ACS-Y-20. In ACS-Y-20, the spiral strength at maximum axial load was $754 \mathrm{MPa}$, i.e., $0.3 \%$ lower than its yield strength, $756 \mathrm{MPa}$. Therefore, it can be assumed that the spiral in ACS-Y-20 yielded at maximum axial load.

From the values in Table 1, it is apparent that given the same amount of spiral, the spiral strain at maximum axial load decreased with increase in concrete strength, as seen in ACS-Y-1, ACS-Y-9, ACS-Y-17, and ACS-Y-25. Spiral strain at maximum axial load decreased with increase in volumetric ratio, as seen in ACS-Y-1, ACS-Y-2, ACS-Y-3, and ACS-Y-4. The main reason for the above phenomenon is that with increase in concrete strength, the concrete Poisson ratio decreases, resulting in a decrease in concrete lateral expansion. With small spiral spacing and large volumetric ratio, the strong restraint of the spiral can effectively limit concrete expansion. Therefore, spiral strain at maximum axial load decreased with increase in concrete strength and volumetric ratio. For specimens in
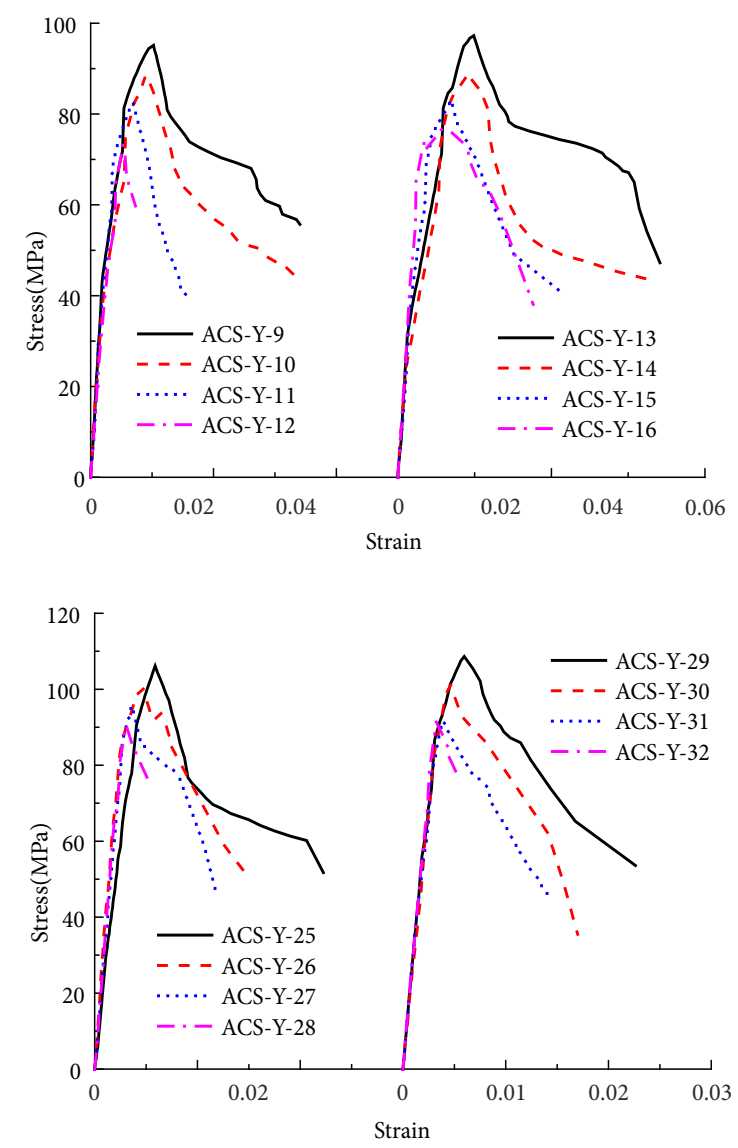

Figure 7. Measured stress-strain curves of test specimens 
which the spirals yielded at maximum axial load, such as ACS-Y-12 and ACS-Y-16, spiral strain at maximum axial load increased with spiral yield strength. However, for specimens in which spiral stress was lower than yield strength at maximum axial load, such as ACS-Y-17, ACS-Y-21, ACS-Y-26, and ACS-Y-30, the effect of spiral yield strength on spiral strain at maximum axial load can be ignored.

Experimental results indicated that the cover spalling occurred prior to the peak load of column. Therefore, the maximum axial load was resisted by the core concrete and the longitudinal reinforcement. The stress of the concrete core was calculated by subtracting the contributions of the longitudinal reinforcement steel and concrete cover, as presented in Eqn (1):

$$
f_{\mathrm{cc}}=\frac{P_{\max }-f_{\mathrm{y}} A_{\mathrm{s}}}{A_{\mathrm{cor}}} \text {. }
$$

In above equation, $P_{\max }$ is the maximum axial load carried by column, $f_{\mathrm{cc}}$ is confined concrete compressive strength, $A_{\text {cor }}$ is the core area of circular section, $f_{\mathrm{y}}$ is the yield strength of longitudinal reinforcement, $A_{\mathrm{s}}$ is the total cross-sectional area of longitudinal reinforcement.

The stress-strain curves of confined concrete were applied to analyse the behaviour of the specimens. The stress-strain curves of confined concrete are shown in Figure 7. The test results of confined concrete compressive stress $f_{\mathrm{cc}}$, strain $\varepsilon_{\mathrm{cc}}$ and corresponding spiral strain $\varepsilon_{\mathrm{sv}}$ are shown in Table 1 .

\section{Effect of test variables on stress-strain curve of confined concrete}

\subsection{Unconfined concrete compressive strength}

Unconfined concrete compressive strength is an important variable influencing the behaviour of confined concrete. Specimens with identical diameters, spacings, and arrangement of spirals but different unconfined concrete compressive strength values were tested to quantify the influence of unconfined concrete compressive strength.
The experimental results were compared on the stressstrain curves of confined concrete. Sample comparisons are shown in Figure 8 involving columns with unconfined concrete compressive strength values of $47.09 \mathrm{MPa}$, 59.44 MPa, 68.59 MPa, and 75.64 MPa. The results indicated a consistent decrease in peak strain $\varepsilon_{\mathrm{cc}}$ and ultimate strain. Besides, confined concrete compressive strength $f_{\text {cc }}$ increased with unconfined concrete compressive strength $f_{\mathrm{c}}$. The descending parts of the stress-strain curves became steep and short at higher values of $f_{c}$.

\subsection{Volumetric ratio}

The passive confinement pressure developed in columns is a function of the amount of confinement reinforcement provided. The increasing in amount of specific grade of spiral expressed in terms of volumetric ratio. The influence of volumetric ratio was investigated by testing specimens with different volumetric ratios, all other properties being identical. The experimental results are compared on the stress-strain curves of confined concrete. Sample comparisons are shown in Figure 9 involving columns with volumetric ratios of $2.0 \%, 1.6 \%, 1.2 \%$ and $0.9 \%$. The experimental results indicate that confined concrete compressive strength $f_{\mathrm{cc}}$, peak strain $\varepsilon_{\mathrm{cc}}$ and ultimate strain increased with volumetric ratio. Furthermore, when the volumetric ratio was low, as for ACS-Y-8, ACS-Y-16, ACS-Y-24, and ACS-Y-32, the specimens were observed to exhibit in brittle behaviour, showing high rate of strength decay immediately after the confined concrete compressive strength. The descending parts of the stress-strain curves became steep and short at low volumetric ratios. The test results indicated that it is necessary to limit the minimum spiral volumetric ratio to ensure ductile behavior of highstrength confined concrete, as was evident by behaviour of specimens ACS-Y-24, ACS-Y-32, and so on.

\subsection{Spiral yield strength}

Passive confinement pressure is generated from the tensile forces that develop in the spiral as the consequence of lateral expansion, which depends on the mechanical

b) $\rho_{\mathrm{v}}=0.9 \%$

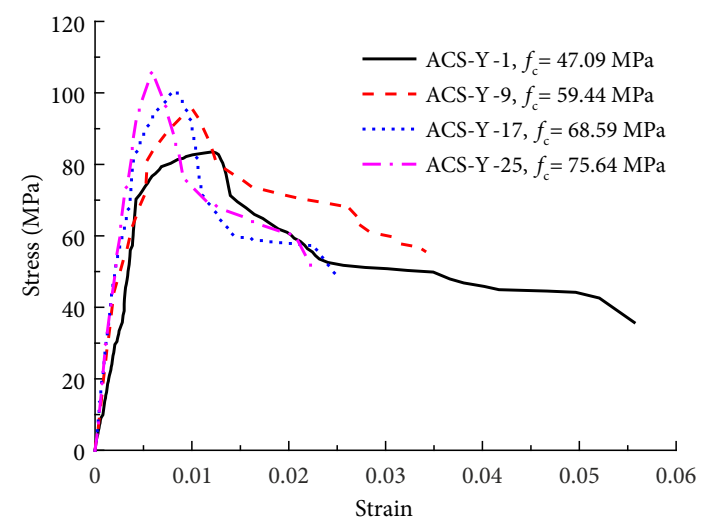

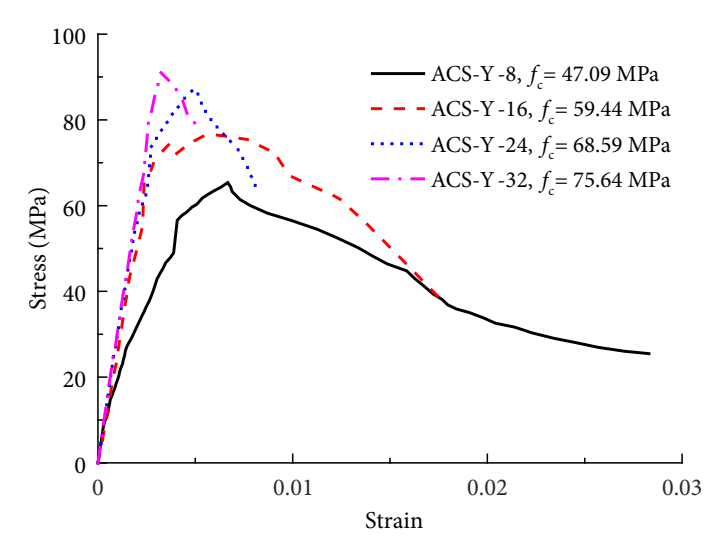

Figure 8. Influence of unconfined concrete compressive strength on stress-strain curve 
properties of concrete. Thus, the effectiveness of highstrength spiral depends on the lateral expansion ability of concrete. The higher strength concrete exhibits less lateral expansion ability than lower strength concrete due to its higher elasticity modulus and lower internal micro cracking. The higher strength concrete is, the lower spiral stress is.

The effect of spiral yield strength was investigated by testing specimens with the identical unconfined concrete compressive strength, volumetric ratio, and diameter and spacing of spiral, but with different yield strength values, as shown in Figure 10. The comparison shown in Figure 10 indicates that both confined concrete compressive strength $f_{\mathrm{cc}}$ and peak strain $\varepsilon_{\mathrm{cc}}$ increased with spiral yield strength if the spiral could yield at confined concrete compressive strength, such as for ACS-Y-4 and ACSY-8. However, for those specimens in which spiral stress at confined concrete compressive strength was less than yield strength, spiral yield strength had slight influence on confined concrete compressive strength $f_{\mathrm{cc}}$ and peak strain $\varepsilon_{\mathrm{cc}}$. Therefore, increasing the spiral yield strength can be effective only if the yield strength of spiral is fully developed prior to confined concrete compressive strength (Sharma et al., 2005), and the full yield strength of highstrength spiral cannot be used in calculating the confining stress.

a) $f_{\mathrm{c}}=59.44 \mathrm{MPa}$

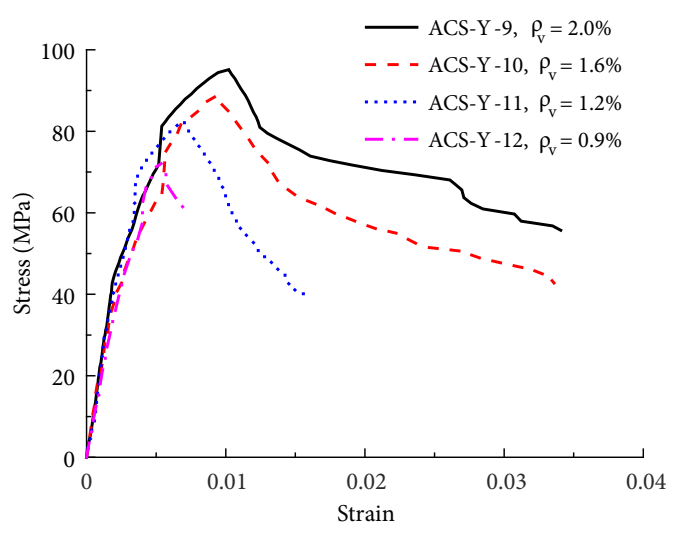

\section{Confinement model of confined concrete}

Spiral yield strength has been used as a substitute for spiral stress at confined concrete compressive strength in most confinement models to compute lateral pressure. This assumption may be suitable for normal-strength concrete columns confined by normal-strength spirals, but may cause errors in HSC columns confined by high-strength spirals (Razvi \& Saatcioglu, 1999a). Therefore, based on previous confinement models, a modified confinement model is proposed to predict spiral stress in the computation of lateral pressure.

\subsection{Spiral stress at confined concrete compressive strength}

To compute spiral stress $\sigma_{\mathrm{sv}}$ at confined concrete compressive strength $f_{\mathrm{cc}}$, the corresponding spiral strain $\varepsilon_{\mathrm{sv}}$ must be estimated. From the above analysis, when the spiral did not yield at confined concrete compressive strength, spiral strain at confined concrete compressive strength decreased with increase in concrete strength and volumetric ratio, as shown in Figure 11. Therefore, an equation was proposed to calculate spiral strain $\varepsilon_{\mathrm{sv}}$ at confined concrete compressive strength of confined concrete, as presented in Eqn (2):

b) $f_{\mathrm{c}}=75.64 \mathrm{MPa}$

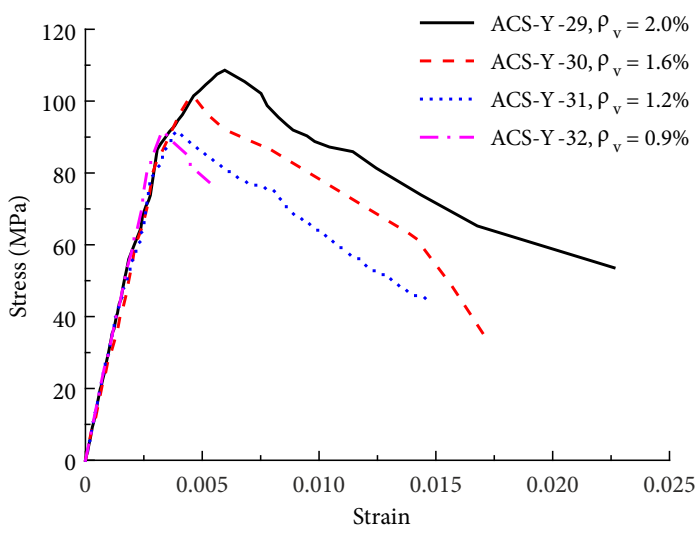

Figure 9. Influence of volumetric ratio on stress-strain curve
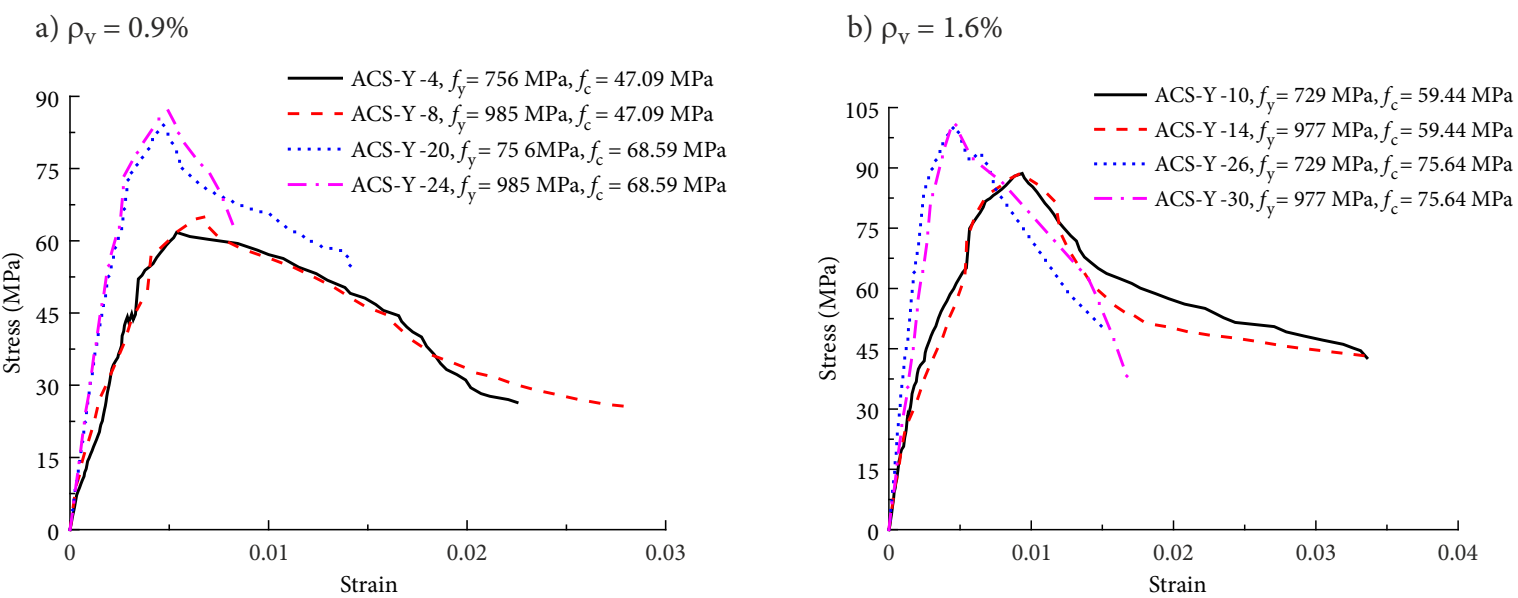

Figure 10. Influence of spiral yield strength on stress-strain curve 


$$
\varepsilon_{\mathrm{sv}}=7.18 \times 10^{-8} \frac{E_{\mathrm{c}}}{\rho_{\mathrm{v}} f_{\mathrm{c}}}+1.11 \times 10^{-3} .
$$

In above equation, $E_{\mathrm{c}}$ is the modulus of elasticity for concrete which can be calculated as Eqn (3) (China Architecture \& Building Press, 2011), $\rho_{\mathrm{v}}$ is volumetric ratio, and $f_{\mathrm{c}}$ is unconfined concrete compressive strength:

$$
E_{\mathrm{c}}=\frac{10^{5}}{2.2+\frac{34.7}{f_{\mathrm{ck}, \text { cube }}}} .
$$

In the above equation, $f_{\text {ck,cube }}$ is the characteristic value of cube compressive strength of concrete.

The spiral stress $\sigma_{\mathrm{sv}}$ at confined concrete compressive strength $f_{\text {cc }}$ can be calculated according to the stress-strain curve of steel bars. If the spiral stress $\sigma_{\mathrm{sv}}$ at confined concrete compressive strength $f_{\mathrm{cc}}$ exceeds yield strength, the former adopts the latter.

\subsection{Effective confinement pressure and effective confinement index}

Based on the equilibrium of lateral pressure applied on the concrete core and the confining reinforcement forces, the nominal lateral pressure can be calculated as follows:

$$
f_{l}=\frac{2 A_{\mathrm{sv} 1} \sigma_{\mathrm{sv}}}{D_{\mathrm{cor}} s} .
$$

In the above equation, $A_{\mathrm{sv} 1}$ is the cross-sectional area of a single spiral, $\sigma_{\mathrm{sv}}$ is the spiral stress at confined concrete compressive strength, $D_{\text {cor }}$ is the core diameter of the circular section, and $s$ is the centre-to-centre spiral spacing.

The nominal lateral pressure $f_{l}$ from spiral can be fully applied only to the part of the concrete core where the confining stress has completely developed due to the arching action (Mander et al., 1988). The Figure 12 shows the arching action that is assumed to occur between the levels of spiral. The ineffectively confined concrete area will be largest and the effectively confined concrete core area will be smallest $\left(A_{\mathrm{e}}\right)$ in the midway between the levels of the spiral.

When using lateral pressure to compute the strength and ductility of confined concrete columns, it is assumed for convenience that the area of the concrete with the center lines of the perimeter spiral $\left(A_{\text {cor }}\right)$ is the area of the confined concrete. In order to allow for the fact that the effectively confined concrete core area is smaller than the area of the concrete with the center liner of the perimeter spiral $\left(A_{\mathrm{e}}<A_{\text {cor }}\right)$, the effective confinement pressure which is the product of the nominal lateral pressure by the confinement effectiveness coefficient is used in computing the strength and ductility of confined concrete columns. Mode Code 2010 gives the effective confinement pressure calculation method applied to the nominal concrete core, as seen in the following equation:

$$
f_{l e}=k_{\mathrm{e}} f_{l}=\left(1-\frac{s}{D_{\text {cor }}}\right) \frac{2 A_{\mathrm{sv} 1} \sigma_{\mathrm{sv}}}{D_{\mathrm{cor}} s}=\frac{1}{2} \rho_{\mathrm{v}} \sigma_{\mathrm{sv}}\left(1-\frac{s}{D_{\text {cor }}}\right) .
$$

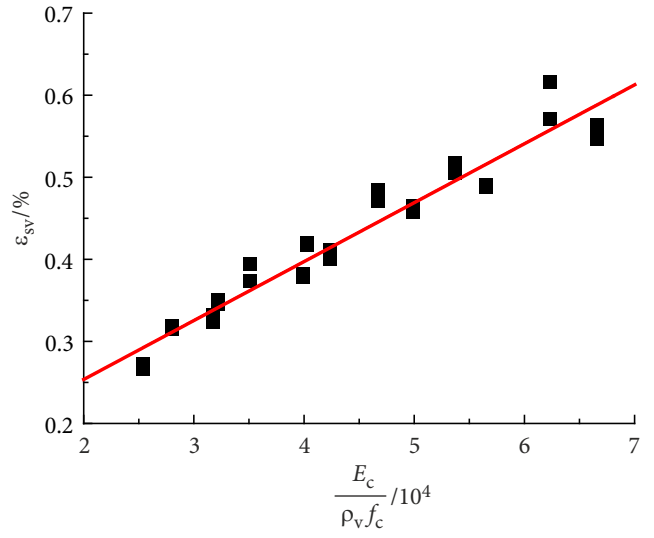

Figure 11. Fitting curve of spiral strain at confined concrete compressive strength

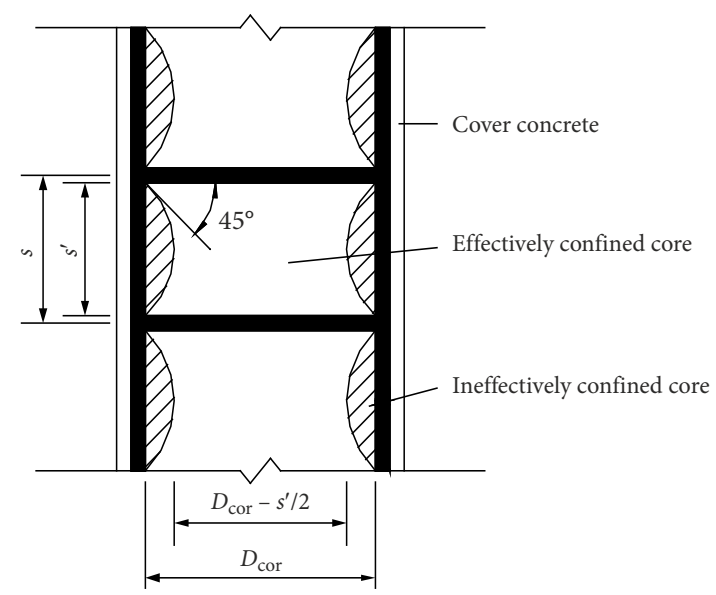

Figure 12. Effectively confined core for circular columns confined by spiral

In the above equation, $k_{\mathrm{e}}$ is the confinement effectiveness coefficient, for circular cross-section confined by spiral, $k_{\mathrm{e}}=1-\frac{s}{D_{\text {cor }}}$.

\subsection{Regression analysis of strength, strain, and ductility}

A regression analysis was performed on all the test results of the specimens listed in Table 1, those of Razvi (1995), Razvi and Saatcioglu (1999a) in Table 3 and those of Wang et al. (2017) in Table 4 to formulate the confined concrete compressive strength $f_{\mathrm{cc}}$, corresponding peak strain $\varepsilon_{\mathrm{cc}}$, and strain $\varepsilon_{0.85}$. The effective confinement pressure $f_{\mathrm{le}}$ is calculated from Eqn (5) with $\sigma_{\mathrm{sv}^{\circ}}$ Based on the method of least absolute deviations method, the results of the regression analysis are as follows:

$$
\begin{aligned}
& \frac{f_{\mathrm{cc}}}{f_{\mathrm{c}}}=1+5.3 \times\left(\frac{f_{\mathrm{le}}}{f_{\mathrm{c}}}\right) ; \\
& \frac{\varepsilon_{\mathrm{cc}}}{\varepsilon_{\mathrm{co}}}=1+50 \times\left(\frac{f_{\mathrm{le}}}{f_{\mathrm{c}}}\right)^{1.14} ; \\
& \frac{\varepsilon_{0.85}}{\varepsilon_{\mathrm{co}}}=1+18 \times\left(\frac{f_{\mathrm{le}}}{f_{\mathrm{c}}}\right)^{0.57} .
\end{aligned}
$$


Table 3. Specimen properties and test results of Razvi (1995), Razvi and Saatcioglu (1999a)

\begin{tabular}{|c|c|c|c|c|c|c|c|c|}
\hline Specimen number & $f_{\mathrm{c}} / \mathrm{MPa}$ & $f_{\mathrm{yv}} / \mathrm{MPa}$ & $d / \mathrm{mm}$ & $s / \mathrm{mm}$ & $\rho_{\mathrm{v}} / \%$ & $f_{\mathrm{cc}} / \mathrm{MPa}$ & $\varepsilon_{\mathrm{cc}} / \%$ & $\varepsilon_{0.85} / \%$ \\
\hline CC-1 & 60 & 660 & 6 & 135 & 0.41 & 59.67 & 0.41 & 0.66 \\
\hline CC-3 & 60 & 660 & 6.3 & 70 & 0.80 & 68.34 & 0.54 & 0.90 \\
\hline CC-4 & 60 & 660 & 6.3 & 70 & 0.80 & 67.32 & 0.45 & 0.73 \\
\hline CC-5 & 60 & 660 & 6.3 & 70 & 0.80 & 61.71 & 0.41 & - \\
\hline CC-6 & 60 & 660 & 6.3 & 135 & 0.41 & 56.61 & 0.39 & - \\
\hline CC-8 & 124 & 660 & 6.3 & 70 & 0.80 & 123.32 & 0.31 & 0.5 \\
\hline CC-11 & 124 & 660 & 6.3 & 60 & 0.93 & 124.37 & 0.33 & 0.53 \\
\hline CC-12 & 124 & 1000 & 7.5 & 60 & 1.32 & 127.53 & 0.33 & 1.00 \\
\hline CC-14 & 92 & 1000 & 7.5 & 60 & 1.32 & 102.44 & 0.35 & 0.88 \\
\hline CC-16 & 92 & 1000 & 7.5 & 100 & 0.79 & 95.40 & 0.37 & 0.58 \\
\hline CC-17 & 92 & 1000 & 7.5 & 60 & 1.32 & 89.15 & 0.30 & 0.63 \\
\hline CC-18 & 92 & 1000 & 7.5 & 100 & 0.79 & 82.89 & 0.30 & 0.64 \\
\hline CC-20 & 92 & 660 & 6.3 & 100 & 0.56 & 88.37 & 0.28 & 0.42 \\
\hline CC-21 & 92 & 660 & 6.3 & 70 & 0.80 & 93.06 & 0.33 & 0.67 \\
\hline
\end{tabular}

Table 4. Specimen properties and test results of Wang et al. (2017)

\begin{tabular}{|c|c|c|c|c|c|c|c|c|}
\hline Specimen number & $f_{\mathrm{c}} / \mathrm{MPa}$ & $f_{\mathrm{yv}} / \mathrm{MPa}$ & $d / \mathrm{mm}$ & $s / \mathrm{mm}$ & $\rho_{\mathrm{v}} / \%$ & $f_{\mathrm{cc}} / \mathrm{MPa}$ & $\varepsilon_{\mathrm{cc}} / \%$ & $\varepsilon_{0.85} / \%$ \\
\hline A1 & 79.45 & 515 & 8 & 55 & 1.41 & 79.94 & 0.459 & 1.014 \\
\hline A2 & 79.45 & 515 & 8 & 80 & 0.97 & 85.31 & 0.401 & 0.570 \\
\hline A3 & 79.45 & 515 & 8 & 110 & 0.70 & 75.20 & 0.342 & 0.777 \\
\hline A4 & 79.45 & 515 & 8 & 160 & 0.48 & 74.50 & 0.383 & 0.514 \\
\hline A5 & 79.45 & 515 & 8 & 55 & 1.41 & 76.88 & - & - \\
\hline A6 & 79.45 & 515 & 8 & 55 & 1.41 & 85.34 & 0.400 & 0.673 \\
\hline B1 & 92.61 & 515 & 8 & 55 & 1.41 & 100.23 & 0.450 & 1.255 \\
\hline B2 & 92.61 & 515 & 8 & 80 & 0.97 & 97.20 & 0.382 & - \\
\hline B3 & 92.61 & 515 & 8 & 110 & 0.70 & 96.18 & - & - \\
\hline B4 & 92.61 & 515 & 8 & 160 & 0.48 & 95.85 & 0.343 & - \\
\hline B5 & 92.61 & 515 & 8 & 55 & 1.41 & 90.74 & 0.371 & 0.749 \\
\hline B6 & 92.61 & 515 & 8 & 55 & 1.41 & 103.29 & 0.421 & 1.115 \\
\hline C1 & 109.78 & 515 & 8 & 55 & 1.41 & 114.09 & 0.614 & 0.902 \\
\hline C2 & 109.78 & 515 & 8 & 80 & 0.97 & 109.71 & 0.323 & - \\
\hline C3 & 109.78 & 515 & 8 & 110 & 0.70 & 114.46 & 0.400 & 0.544 \\
\hline C4 & 109.78 & 515 & 8 & 160 & 0.48 & 112.09 & - & - \\
\hline C5 & 109.78 & 515 & 8 & 55 & 1.41 & 109.02 & 0.411 & 0.864 \\
\hline C6 & 109.78 & 515 & 8 & 55 & 1.41 & 118.84 & 0.450 & 0.991 \\
\hline
\end{tabular}

Figure 13 shows the relationship between $f_{\mathrm{cc}} / f_{\mathrm{c}}$ and the effective confinement index $f_{\mathrm{le}} / f_{\mathrm{c}}$. Figure 14 shows the relationship between $\varepsilon_{\mathrm{cc}} / \varepsilon_{\mathrm{co}}$ and $f_{\mathrm{le}} / f_{\mathrm{c}}$. Figure 15 illustrates the relationship between $\varepsilon_{0.85} / \varepsilon_{\mathrm{co}}$ and $f_{\mathrm{le}} / f_{\mathrm{c}}$.

\subsection{Modified stress-strain curve}

The ascending part of the stress-strain curve exhibits a relationship originally proposed by Popovics (1973) for concrete and written as:

$$
\begin{aligned}
& f_{\mathrm{c}}=f_{\mathrm{cc}}\left[\frac{k\left(\varepsilon_{\mathrm{c}} / \varepsilon_{\mathrm{cc}}\right)}{k-1+\left(\varepsilon_{\mathrm{c}} / \varepsilon_{\mathrm{cc}}\right)^{k}}\right] \quad\left(\varepsilon_{\mathrm{c}} \leq \varepsilon_{\mathrm{cc}}\right) ; \\
& k=\frac{E_{\mathrm{c}}}{E_{\mathrm{c}}-f_{\mathrm{cc}} / \varepsilon_{\mathrm{cc}}} .
\end{aligned}
$$

In the above equation, $k$ controls the initial slope and curvature of the ascending branch, and $E_{c}$ is the tangent modulus of concrete. For HSCs, the coefficient $k$ is large, and the ascending branch is nearly linear (Popovics, 1973).

The descending part of the stress-strain curve exhibits a relationship proposed by Fafitis and Shah (1985), and described as follows:

$$
\begin{aligned}
& f_{\mathrm{c}}=f_{\mathrm{cc}} \cdot \exp \left[k_{1}\left(\varepsilon_{\mathrm{c}}-\varepsilon_{\mathrm{cc}}\right)^{k_{2}}\right] \quad\left(\varepsilon_{\mathrm{c}} \geq \varepsilon_{\mathrm{cc}}\right) ; \\
& k_{1}=\frac{\ln 0.85}{\left(\varepsilon_{0.85}-\varepsilon_{\mathrm{cc}}\right)^{k_{2}}} ; \\
& k_{2}=0.35+1.04 \times\left(\frac{f_{\mathrm{fle}}}{f_{\mathrm{c}}}\right)^{0.31} .
\end{aligned}
$$




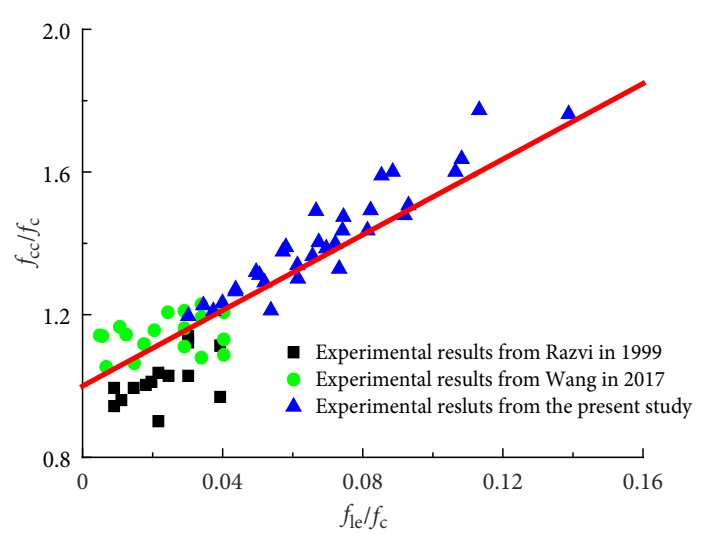

Figure 13. Effect of confinement on confined concrete compressive strength

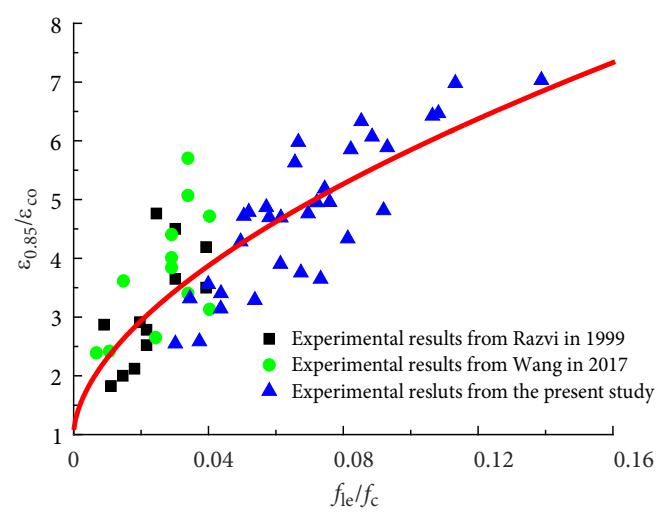

Figure 15. Effect of confinement on ductility of confined concrete

In the above equation, $k_{1}$ controls the general slope of the descending branch, which ensures that the stressstrain curve passes through the point $\left(\varepsilon_{0.85}, 0.85 f_{\mathrm{cc}}\right)$. The coefficient $k_{2}$ controls the curvature of the descending branch. For well-confined concrete, the values of $k_{1}$ and $k_{2}$ are relatively large, and the descending branch is smooth and convex (Fafitis \& Shah, 1985). For lightly confined concrete, the values of $k_{1}$ and $k_{2}$ are relatively small, and the descending branch is steep and concave (Fafitis \& Shah, 1985).

Figure 16 illustrates the effect of confinement on the coefficient $k_{2}$, which can be computed using Eqn (13). The experimental values of $k_{2}$ that minimized the difference between the areas under the experimental and analytical stress-strain curves were selected.

\subsection{Comparison with experimental results}

Table 5 compares the experimental results of the 14 confined concrete columns tested by Razvi (1995), Razvi and Saatcioglu (1999a), 18 confined concrete columns tested by Wang et al. (2017), and 32 confined concrete columns tested in this study with predictions obtained from the proposed confinement model. The average values of the ratios $f_{\mathrm{cc}, \mathrm{c}} / f_{\mathrm{cc}, \mathrm{t}}, \varepsilon_{\mathrm{ccc}, \mathrm{c}} / \varepsilon_{\mathrm{cc}, \mathrm{t}}$, and $\varepsilon_{0.85, \mathrm{c}} / \varepsilon_{0.85, \mathrm{t}}$ are respectively $1.00,0.99$, and 1.00 . The standard deviations of the ratios

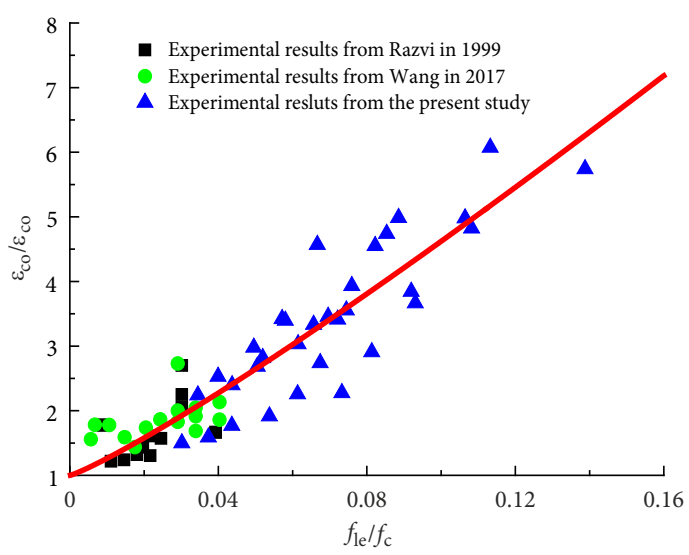

Figure 14. Effect of confinement on peak strain of confined concrete

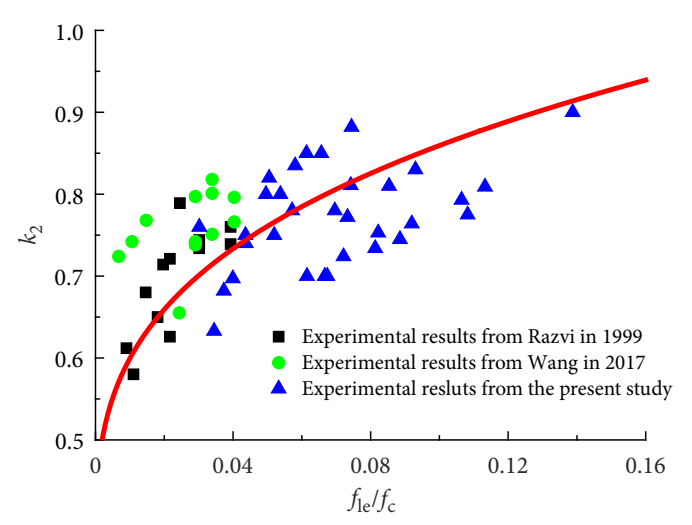

Figure 16. Effect of confinement on coefficient $k_{2}$

$f_{\mathrm{cc}, \mathrm{c}} / f_{\mathrm{cc}, \mathrm{t}}, \varepsilon_{\mathrm{cc}, \mathrm{c}} / \varepsilon_{\mathrm{cc}, \mathrm{t}}$, and $\varepsilon_{0.85, \mathrm{c}} / \varepsilon_{0.85, \mathrm{t}}$ are respectively 0.08 , 0.18 , and 0.18 .

Figure 17 compares the experimental and analytical stress-strain curves of 16 confined concrete column samples. As the spiral stress at confined concrete compressive strength $\sigma_{\mathrm{sv}}$ is computed in the confinement model, the results indicated good agreement between the experimental and analytical curves.

\section{Conclusions}

The results of tests on 32 HSC columns confined by high-strength spiral subjected to compressive loads were presented in this paper. In this study, we proposed a confinement model suitable for HSC columns confined by high-strength spirals. Based on the above investigations, the following concluding remarks are made:

1. There are two types of failure pattern: bulging and shear sliding. The bulging failure pattern was mostly observed in specimens with closely spaced spirals while the shear sliding failure pattern was usually observed in specimens with widely spaced spirals. The higher the unconfined concrete compressive strength, the lower are the ratio of concrete tensile strength to compressive strength and Poisson ratio, and the more prone the column is to shear sliding. 
Table 5. Comparison of experimental results with prediction of confinement model

\begin{tabular}{|c|c|c|c|c|c|c|c|c|c|}
\hline Specimen number & $f_{\mathrm{cc}, \mathrm{t}} / \mathrm{MPa}$ & $f_{\mathrm{cc}, \mathrm{c}} / \mathrm{MPa}$ & $f_{\mathrm{cc}, \mathrm{c}} / f_{\mathrm{cc}, \mathrm{t}}$ & $\varepsilon_{\mathrm{cc}, \mathrm{t}} / \%$ & $\varepsilon_{\mathrm{cc}, \mathrm{c}} / \%$ & $\varepsilon_{\mathrm{cc}, \mathrm{c}} / \varepsilon_{\mathrm{cc}, \mathrm{t}}$ & $\varepsilon_{0.85, \mathrm{t}} / \%$ & $\varepsilon_{0.85, \mathrm{c}} / \%$ & $\varepsilon_{0.85, \mathrm{c}} / \varepsilon_{0.85, \mathrm{t}}$ \\
\hline ACS-Y-1 & 83.51 & 75.35 & 0.90 & 1.21 & 1.03 & 0.85 & 1.40 & 1.24 & 0.89 \\
\hline ACS-Y-2 & 74.88 & 68.39 & 0.91 & 0.95 & 0.80 & 0.85 & 1.27 & 1.09 & 0.86 \\
\hline ACS-Y-3 & 69.42 & 65.68 & 0.95 & 0.71 & 0.72 & 1.01 & 1.04 & 1.02 & 0.98 \\
\hline ACS-Y-4 & 61.76 & 59.69 & 0.97 & 0.54 & 0.53 & 0.99 & 0.94 & 0.86 & 0.91 \\
\hline ACS-Y-5 & 82.98 & 81.72 & 0.98 & 1.15 & 1.25 & 1.09 & 1.41 & 1.37 & 0.97 \\
\hline ACS-Y-6 & 75.37 & 73.66 & 0.98 & 1.00 & 0.98 & 0.98 & 1.29 & 1.20 & 0.94 \\
\hline ACS-Y-7 & 70.94 & 70.31 & 0.99 & 0.73 & 0.87 & 1.18 & 1.18 & 1.13 & 0.96 \\
\hline ACS-Y-8 & 64.23 & 63.48 & 0.99 & 0.67 & 0.65 & 0.97 & 1.13 & 0.96 & 0.85 \\
\hline ACS-Y-9 & 95.14 & 87.33 & 0.92 & 1.02 & 0.85 & 0.83 & 1.24 & 1.13 & 0.91 \\
\hline ACS-Y-10 & 88.61 & 80.43 & 0.91 & 0.94 & 0.67 & 0.72 & 1.23 & 0.99 & 0.81 \\
\hline ACS-Y-11 & 82.59 & 77.72 & 0.94 & 0.70 & 0.60 & 0.87 & 0.96 & 0.93 & 0.97 \\
\hline ACS-Y-12 & 73.26 & 72.02 & 0.98 & 0.52 & 0.47 & 0.90 & 0.73 & 0.79 & 1.09 \\
\hline ACS-Y-13 & 97.26 & 93.53 & 0.96 & 0.99 & 1.02 & 1.03 & 1.33 & 1.24 & 0.94 \\
\hline ACS-Y-14 & 88.72 & 85.34 & 0.96 & 0.93 & 0.80 & 0.86 & 1.20 & 1.09 & 0.91 \\
\hline ACS-Y-15 & 83.14 & 82.16 & 0.99 & 0.70 & 0.72 & 1.02 & 1.01 & 1.03 & 1.01 \\
\hline ACS-Y-16 & 76.69 & 75.81 & 0.99 & 0.58 & 0.56 & 0.96 & 0.98 & 0.89 & 0.91 \\
\hline ACS-Y-17 & 100.76 & 97.78 & 0.97 & 0.83 & 0.77 & 0.93 & 1.04 & 1.08 & 1.04 \\
\hline ACS-Y-18 & 94.45 & 89.38 & 0.95 & 0.72 & 0.61 & 0.85 & 1.02 & 0.95 & 0.93 \\
\hline ACS-Y-19 & 90.54 & 86.60 & 0.96 & 0.63 & 0.55 & 0.88 & 0.90 & 0.89 & 0.99 \\
\hline ACS-Y-20 & 84.11 & 81.12 & 0.96 & 0.47 & 0.44 & 0.93 & 0.70 & 0.76 & 1.10 \\
\hline ACS-Y-21 & 101.45 & 102.02 & 1.01 & 0.81 & 0.90 & 1.12 & 1.01 & 1.18 & 1.17 \\
\hline ACS-Y-22 & 95.05 & 93.88 & 0.99 & 0.73 & 0.71 & 0.98 & 1.00 & 1.04 & 1.04 \\
\hline ACS-Y-23 & 89.24 & 90.94 & 1.02 & 0.64 & 0.65 & 1.02 & 0.99 & 0.98 & 1.00 \\
\hline ACS-Y-24 & 87.18 & 84.48 & 0.97 & 0.50 & 0.51 & 1.00 & 0.71 & 0.84 & 1.18 \\
\hline ACS-Y-25 & 106.14 & 102.66 & 0.97 & 0.59 & 0.71 & 1.21 & 0.81 & 1.02 & 1.27 \\
\hline ACS-Y-26 & 100.49 & 105.02 & 1.05 & 0.47 & 0.60 & 1.28 & 0.75 & 0.97 & 1.30 \\
\hline ACS-Y-27 & 95.71 & 93.13 & 0.97 & 0.36 & 0.44 & 1.22 & 0.64 & 0.80 & 1.25 \\
\hline ACS-Y-28 & 90.49 & 87.74 & 0.97 & 0.31 & 0.37 & 1.20 & 0.52 & 0.67 & 1.29 \\
\hline ACS-Y-29 & 108.62 & 108.24 & 1.00 & 0.60 & 0.74 & 1.23 & 0.89 & 1.07 & 1.20 \\
\hline ACS-Y-30 & 101.27 & 100.24 & 0.99 & 0.46 & 0.59 & 1.26 & 0.80 & 0.94 & 1.17 \\
\hline ACS-Y-31 & 91.65 & 97.19 & 1.06 & 0.39 & 0.51 & 1.30 & 0.67 & 0.86 & 1.28 \\
\hline ACS-Y-32 & 91.53 & 90.60 & 0.99 & 0.33 & 0.40 & 1.24 & 0.53 & 0.69 & 1.29 \\
\hline CC-1 & 59.67 & 62.87 & 1.05 & 0.41 & 0.29 & 0.70 & 0.66 & 0.51 & 0.78 \\
\hline CC-3 & 68.34 & 69.60 & 1.02 & 0.54 & 0.38 & 0.71 & 0.90 & 0.69 & 0.77 \\
\hline CC-4 & 67.32 & 69.60 & 1.03 & 0.45 & 0.38 & 0.86 & 0.73 & 0.69 & 0.94 \\
\hline CC-5 & 61.71 & 69.60 & 1.13 & 0.41 & 0.38 & 0.94 & - & - & - \\
\hline CC-6 & 56.61 & 62.87 & 1.11 & 0.39 & 0.27 & 0.70 & - & - & - \\
\hline CC-8 & 123.32 & 133.60 & 1.08 & 0.31 & 0.35 & 1.13 & 0.50 & 0.64 & 1.28 \\
\hline CC-11 & 124.37 & 135.89 & 1.09 & 0.33 & 0.38 & 1.15 & 0.53 & 0.69 & 1.30 \\
\hline CC-12 & 127.53 & 140.13 & 1.10 & 0.33 & 0.36 & 1.10 & 1.00 & 0.70 & 0.70 \\
\hline CC-14 & 102.44 & 111.33 & 1.09 & 0.35 & 0.46 & 1.31 & 0.88 & 0.81 & 0.92 \\
\hline CC-16 & 95.40 & 102.55 & 1.07 & 0.37 & 0.38 & 1.01 & 0.58 & 0.70 & 1.20 \\
\hline CC-17 & 89.15 & 111.33 & 1.25 & 0.30 & 0.39 & 1.29 & 0.63 & 0.69 & 1.10 \\
\hline CC-18 & 82.89 & 102.55 & 1.24 & 0.30 & 0.38 & 1.25 & 0.64 & 0.70 & 1.09 \\
\hline CC-20 & 88.37 & 97.40 & 1.10 & 0.28 & 0.30 & 1.06 & 0.42 & 0.55 & 1.30 \\
\hline CC-21 & 93.06 & 101.60 & 1.09 & 0.33 & 0.36 & 1.09 & 0.67 & 0.67 & 1.00 \\
\hline $\mathrm{A} 1$ & 79.94 & 94.57 & 1.18 & 0.459 & 0.46 & 1.00 & 1.014 & 0.80 & 0.79 \\
\hline A2 & 85.31 & 88.58 & 1.04 & 0.401 & 0.35 & 0.88 & 0.570 & 0.65 & 1.14 \\
\hline
\end{tabular}


End of Table 5

\begin{tabular}{|c|c|c|c|c|c|c|c|c|c|}
\hline Specimen number & $f_{\mathrm{cc}, \mathrm{t}} / \mathrm{MPa}$ & $f_{\mathrm{cc}, \mathrm{c}} / \mathrm{MPa}$ & $f_{\mathrm{cc}, \mathrm{c}} / f_{\mathrm{cc}, \mathrm{t}}$ & $\varepsilon_{\mathrm{cc}, \mathrm{t}} / \%$ & $\varepsilon_{\mathrm{cc}, \mathrm{c}} / \%$ & $\varepsilon_{\mathrm{cc}, \mathrm{c}} / \varepsilon_{\mathrm{cc}, \mathrm{t}}$ & $\varepsilon_{0.85, \mathrm{t}} / \%$ & $\varepsilon_{0.85, \mathrm{c}} / \%$ & $\varepsilon_{0.85, \mathrm{c}} / \varepsilon_{0.85, \mathrm{t}}$ \\
\hline A3 & 75.20 & 84.98 & 1.13 & 0.342 & 0.29 & 0.85 & 0.777 & 0.54 & 0.70 \\
\hline $\mathrm{A} 4$ & 74.50 & 81.99 & 1.10 & 0.383 & 0.27 & 0.69 & 0.514 & 0.42 & 0.83 \\
\hline A5 & 76.88 & 94.57 & 1.23 & - & - & 0 & - & - & - \\
\hline A6 & 85.34 & 94.57 & 1.11 & 0.400 & 0.46 & 1.14 & 0.673 & 0.80 & 1.18 \\
\hline $\mathrm{B} 1$ & 100.23 & 107.73 & 1.07 & 0.450 & 0.43 & 0.95 & 1.255 & 0.85 & 0.67 \\
\hline B2 & 97.20 & 101.74 & 1.05 & 0.382 & 0.34 & 0.88 & - & - & - \\
\hline B3 & 96.18 & 98.14 & 1.02 & - & - & 0 & - & - & - \\
\hline B4 & 95.85 & 95.15 & 0.99 & 0.343 & 0.25 & 0.72 & - & - & - \\
\hline B5 & 90.74 & 107.73 & 1.19 & 0.371 & 0.43 & 1.15 & 0.749 & 0.76 & 1.02 \\
\hline B6 & 103.29 & 107.73 & 1.04 & 0.421 & 0.43 & 1.02 & 1.115 & 0.76 & 0.69 \\
\hline $\mathrm{C} 1$ & 114.09 & 124.90 & 1.09 & 0.614 & 0.41 & 0.66 & 0.902 & 0.73 & 0.81 \\
\hline $\mathrm{C} 2$ & 109.71 & 118.91 & 1.08 & 0.323 & 0.32 & 1.00 & - & - & - \\
\hline C3 & 114.46 & 115.31 & 1.01 & 0.400 & 0.28 & 0.70 & 0.544 & 0.51 & 0.94 \\
\hline $\mathrm{C} 4$ & 112.09 & 112.32 & 1.00 & - & - & 0 & - & - & - \\
\hline C5 & 109.02 & 124.90 & 1.15 & 0.411 & 0.40 & 0.97 & 0.864 & 0.73 & 0.85 \\
\hline C6 & 118.84 & 124.90 & 1.05 & 0.450 & 0.40 & 0.89 & 0.991 & 0.73 & 0.74 \\
\hline Average & - & - & 1.00 & - & - & 1.00 & - & - & 1.01 \\
\hline Standard deviation & - & - & 0.07 & - & - & 0.17 & - & - & 0.18 \\
\hline
\end{tabular}

Note: $f_{\mathrm{cc}, \mathrm{t}}$ is the test value of confined concrete compressive strength; $f_{\mathrm{cc}, \mathrm{c}}$ is the calculated value of confined concrete compressive strength; $\varepsilon_{c c, t}$ is the test value of strain at maximum strength of confined concrete; $\varepsilon_{c c, c}$ is the calculated value of strain at maximum strength of confined concrete; $\varepsilon_{0.85, \mathrm{t}}$ is the test value of strain corresponding to $85 \%$ of confined concrete compressive strength on the descending branch; and $\varepsilon_{0.85, \mathrm{c}}$ is the calculated value of strain corresponding to $85 \%$ of confined concrete compressive strength on the descending branch.
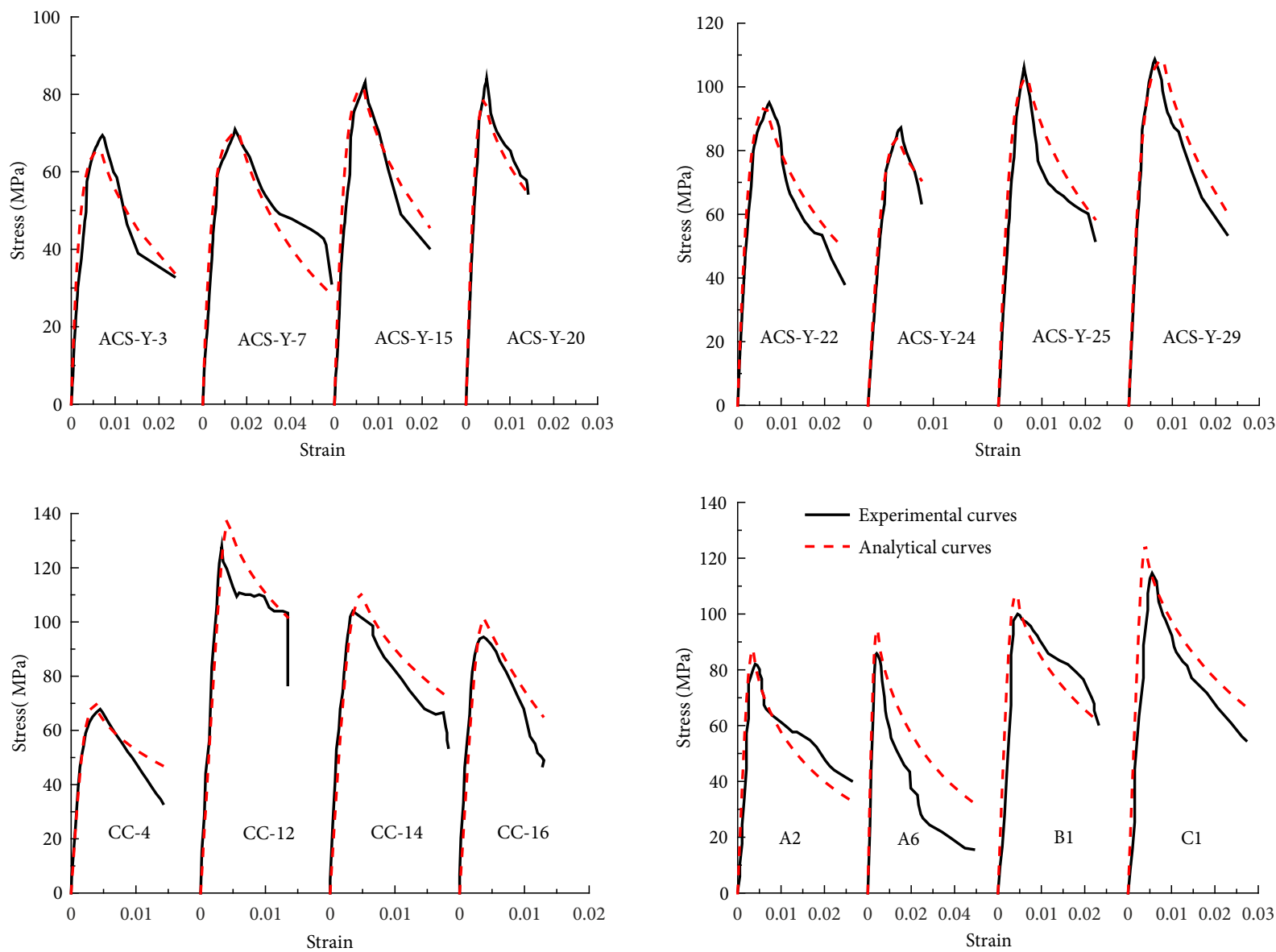

Figure 17. Comparison between analytical and experimental stress-strain curves of confined concrete column samples 
2. The experiment indicated that when unconfined concrete compressive strength was less than $60 \mathrm{MPa}$, the spiral did not yield at confined concrete compressive strength with volumetric ratio of $1.2 \sim 2.0 \%$ but yielded at confined concrete compressive strength with the volumetric ratio of $0.9 \%$ (ACS-Y-4, ACS-Y-8, ACS-Y-12, and ACS-Y-16). The spirals of all columns with unconfined concrete compressive strength ranging from $69 \mathrm{MPa}$ to $76 \mathrm{MPa}$ did not yield at confined concrete compressive strength, except for ACS-Y-20. From the experimental results, it was indicated that when the spiral did not yield at confined concrete compressive strength, the spiral strain at confined concrete compressive strength decreased with increases in concrete strength and volumetric ratio, and the yield strength of the spiral had little influence on spiral strain at confined concrete compressive strength.

3. A consistent decrease in peak strain $\varepsilon_{c c}$ and an increase in confined concrete compressive strength $f_{\mathrm{cc}}$ were observed with increase in unconfined concrete strength $f_{c}$. Increasing the volumetric ratio led to increases in both $f_{\mathrm{cc}}$ and $\varepsilon_{\mathrm{cc}}$. Additionally, both $f_{\mathrm{cc}}$ and $\varepsilon_{\mathrm{cc}}$ increased with spiral yield strength if the spiral could yield at confined concrete compressive strength, but spiral yield strength had slight influence on $f_{\mathrm{cc}}$ and $\varepsilon_{\mathrm{cc}}$ if spiral stress was less than yield strength at confined concrete compressive strength.

4. An equation of predicting spiral strain at confined concrete compressive strength and an analytical confinement model for HSC columns confined by highstrength spirals were proposed. The confinement model used the predicted value of spiral stress at confined concrete compressive strength to replace spiral yield strength in calculating the feature points of the stressstrain curve of confined concrete. The proposed model showed good correlations with available experimental results of 64 columns.

\section{Acknowledgements}

This work was financially supported by the National Natural Science Foundation of China (Grant No. 51678190). The authors would like to express their gratitude to members of the lab office for helping completing experiments. The authors would also like to thank members of the HIT 525 office for their selfless help and useful suggestion.

\section{Funding}

This work was supported by the $<$ National Natural Science Foundation of China> under Grant [number 51678190].

\section{Author contributions}

Wenzhong Zheng and Chongchi Hou conceived the study and were responsible for the design and development of the data analysis. Chongchi Hou was responsible for the experiment, analysis, writing and revising artical. Wei Chang helped perform the experiment.

\section{Disclosure statement}

All the authors have no conflict of interest.

\section{References}

Afifi, M. Z., Mohamed, H. M., \& Benmokrane, B. (2014). Axial capacity of circular concrete columns reinforced with GFRP bars and spirals. Journal of Composites for Construction, 18(1), 04013017.

https://doi.org/10.1061/(ASCE)CC.1943-5614.0000438

Afifi, M. Z., Mohamed, H. M., \& Benmokrane, B. (2015). Theoretical stress-strain model for circular concrete columns confined by GFRP spirals and hoops. Engineering Structures, 102, 202-213. https://doi.org/10.1016/j.engstruct.2015.08.020

Akiyama, M., Suzuki, M., \& Frangopol, D. M. (2010). Stressaveraged strain model for confined high-strength concrete. ACI Structural Journal, 107(2), 179-188.

https://doi.org/10.14359/51663534

American Concrete Institute (ACI). (2019). ACI 318-19: Building code requirements for structural concrete and commentary.

Antonius. (2014). Performance of high-strength concrete columns confined by medium strength of spirals and hoops. Asian Journal of Civil Engineering, 15(2), 245-258.

Assa, B., Nishiyama, M., \& Watanabe, F. (2001a). New approach for modeling confined concrete I: circle columns. Journal of Structural Engineering, 127(7), 743-750.

https://doi.org/10.1061/(ASCE)0733-9445(2001)127:7(743)

Assa, B., Nishiyama, M., \& Watanabe, F. (2001b). New approach for modeling confined concrete II: rectangular columns. Journal of Structural Engineering, 127(7), 751-757. https://doi.org/10.1061/(ASCE)0733-9445(2001)127:7(751)

ASTM International. (2010). ASTM D695-10: Standard test method for compressive properties of rigid plastics.

ASTM International. (2014). ASTM D638-14: Standard test method for tensile properties of plastics

Baduge, S. K., Mendis, P., \& Ngo, T. (2018). Stress-strain relationship for very-high strength concrete (>100 $\mathrm{MPa})$ confined by lateral reinforcement. Engineering Structures, 177, 795-808. https://doi.org/10.1016/j.engstruct. 2018.08.008

Bing, L., Park, R., \& Tanaka, H. (2001). Stress-strain behavior of high-strength concrete confined by ultra-high- and normalstrength transverse reinforcements. ACI Structural Journal, 98(3), 395-406. https://doi.org/10.14359/10228

Campione, G., \& Minafò, G. (2010). Compressive behavior of short high-strength concrete columns. Engineering Structures, 32(9), 2755-2766.

https://doi.org/10.1016/j.engstruct.2010.04.045

Canadian Standards Association (CSA). (2004). CSA A23.3-04: Design of concrete structures.

China Architecture \& Building Press. (2011). GB50010-2010: Code for design of concrete structures (in Chinese).

Cusson, D., \& Paultre, P. (1994). High-strength concrete columns confined by rectangular ties. Journal of Structural Engineering, 120(3), 783-804.

https://doi.org/10.1061/(ASCE)0733-9445(1994)120:3(783)

Cusson, D., \& Paultre, P. (1995). Stress-strain model for confined high-strength concrete. Journal of Structural Engineering, 121(3), 468-477.

https://doi.org/10.1061/(ASCE)0733-9445(1995)121:3(468)

Eid, R., Kovler, K., David, I., Khoury, W., \& Miller, S. (2018). Behavior and design of high-strength circular reinforced concrete columns subjected to axial compression. Engineering Structures, 173, 472-480.

https://doi.org/10.1016/j.engstruct.2018.06.116 
European Committee for Standardization (CEN). (2004). EN 1992-1-1:2004: Design of concrete structures - Part 1: General rules and rules for buildings.

Fafitis, A., \& Shah, S. P. (1985). Lateral reinforcement for highstrength concrete columns. ACI Special Publication, 87, 213232.

Foster, S. J., \& Attard, M. M. (2008). Strength and ductility of fiber reinforced high strength concrete columns. Journal of Structural Engineering, 127(1), 281-289. https://doi.org/10.1061/(ASCE)0733-9445(2001)127:1(28)

Hadi, M. N. S., \& Zhao, H. (2011). Experimental study of highstrength concrete columns confined with different types of mesh under eccentric and concentric loads. Journal of Materials in Civil Engineering, 23(6), 823-832.

https://doi.org/10.1061/(ASCE)MT.1943-5533.0000234

Han, B., Shin, S., \& Bahn, B. (2003). A model of confined concrete in high-strength reinforced concrete tied columns. Magazine of Concrete Research, 55(3), 203-214. https://doi.org/10.1680/macr.2003.55.3.203

Hong, K. N., Akiyama, M., Yi, S. T., \& Suzuki, M. (2006). Stressstrain behavior of high-strength concrete columns confined by low-volumetric ratio rectangular ties. Magazine of Concrete Research, 58(2), 101-115.

https://doi.org/10.1680/macr.2006.58.2.101

Issa, M. A., \& Toban, H. (1994). Strength and ductility enhancement in high-strength confined concrete. Magazine of Concrete Research, 45(168), 177-189.

https://doi.org/10.1680/macr.1994.46.168.177

Kim, Y.-S., Kim, S.-W., Lee, J.-Y., Lee, J.-M., Kim, H.-G., \& Kim, K.-H. (2016). Prediction of stress-strain behavior of spirally confined concrete considering lateral expansion. Construction and Building Materials, 102, 743-761. https://doi.org/10.1016/j.conbuildmat.2015.11.017

Kim, S.-W., Kim, Y.-S., Lee, J.-Y., \& Kim, K.-H. (2017a). Confined concrete with varying yield strengths of spirals. Magazine of Concrete Research, 69(5), 217-229.

https://doi.org/10.1680/jmacr.16.00053

Kim, C.-S., Park, H.-G., Lee, H.-J., \& Choi, I,-R. (2017b). Eccentric axial load test for high-strength composite columns of various sectional configurations. Journal of Structural Engineering, 143(8), 04017075.

https://doi.org/10.1061/(ASCE)ST.1943-541X.0001803

Legeron F., \& Paultre, P. (2003). Uniaxial confinement model for normal- and high-strength concrete columns. Journal of Structural Engineering, 29(2), 241-252.

https://doi.org/10.1061/(ASCE)0733-9445(2003)129:2(241)

Li, Y., Cao, S., Liang, H., Ni, X., \& Jing, D. (2018). Axial compressive behavior of concrete columns with grade 600MPa reinforcing bars. Engineering Structures, 172, 497507. https://doi.org/10.1016/j.engstruct.2018.06.047

Liao, W.-C., Perceka, W., \& Wang, M. (2017). Experimental study of cyclic behavior of high-strength reinforced concrete columns with different transverse reinforcement detailing configurations. Engineering Structures, 153, 290-301. https://doi.org/10.1016/j.engstruct. 2017.10.011

Mander, J. B., Priestley, M. J. N., \& Park, R. (1988). Theoretical stress-strain model for confined concrete. Journal of Structural Engineering, 114(8), 1804-1825.

https://doi.org/10.1061/(ASCE)0733-9445(1988)114:8(1804)

Ou, Y. C., \& Kurniawan, D. P. (2015a). Effect of axial compression on shear behavior of high-strength reinforced concrete columns. ACI Structural Journal, 112(2), 209-220.

https://doi.org/10.14359/51687300
Ou, Y. C., \& Kurniawan, D. P. (2015b). Shear behavior of reinforced of reinforced concrete columns with high-strength steel and concrete. ACI Structural Journal, 112(1), 35-46. https://doi.org/10.14359/51686822

Paultre, P., Legeron, F., \& Mongeau, D. (2001). Influence of concrete strength and transverse reinforcement yield strength on behavior of high-strength concrete columns. ACI Structural Journal, 98(4), 490-501. https://doi.org/10.14359/10292

Popovics, S. (1973). A numerical approach to the complete stressstrain curve of concrete. Cement and Concrete Research, 3(5), 583-599. https://doi.org/10.1016/0008-8846(73)90096-3

Ramezanianpour, A. A. (2014). Cement replacement materials. Properties, durability, sustainability. Springer, Heidelberg. https://doi.org/10.1007/978-3-642-36721-2

Razvi, S. R. (1995). Confinement of normal and high-strength concrete columns (Dissertation). University of Ottawa.

Razvi, S. R., \& Saatcioglu, M. (1999a). Circular high-strength concrete columns under concentric compression. ACI Structural Journal, 96(5), 817-825. https://doi.org/10.14359/736

Razvi, S. R., \& Saatcioglu, M. (1999b). Confinement model for high strength concrete. Journal of Structural Engineering, 125(3), 281-289. https://doi.org/10.1061/(ASCE)0733-9445(1999)125:3(281)

Razvi, S. W. N., \& Shaikh, M. G. (2018). Effect of confinement on behavior of short concrete column. Procedia Manufacturing, 20, 563-570. https://doi.org/10.1016/j.promfg.2018.02.084

Sharma, U. K., Bhargava, P., \& Kaushik, S. K. (2005). Behavior of confined high strength concrete columns under axial compression. Journal of Advanced Concrete Technology, 3(2), 267-281. https:// doi.org/10.3151/JACT.3.267

Standard Association of New Zealand. (2006). NZS 3101: Concrete structures standard Part 1 - The design of concrete structures.

Taheri, A., Moghadam, A. S., \& Tasnimi, A. A. (2017). Critical factors in displacement ductility assessment of high-strength concrete columns. International Journal of Advanced Structural Engineering, 9(4), 325-340.

https://doi.org/10.1007/s40091-017-0169-6

The International Federation for Structural Concrete (FIB). (2010). CEB-FIB Bulletin 66: Mode code final draft - Volume 2.

Wang, W., Zhang, M., Tang, Y., Zhang, X., \& Ding, X. (2017). Behaviour of high-strength concrete columns confined by spiral reinforcement under uniaxial compression. Construction and Building Materials, 154, 496-503. https://doi.org/10.1016/j.conbuildmat.2017.07.179

Yong, Y. K., Nour, M. G., \& Nawy, E. G. (1988). Behavior of laterally confined high-strength concrete under axial loads. Journal of Structural Engineering, 114(2), 333-351. https://doi.org/10.1061/(ASCE)0733-9445(1988)114:2(332)

Zhang, S., \& Wang, Y. (2004). Failure modes of short columns of high-strength concrete-filled steel tubes. China Civil Engineering Journal, 37(9), 1-10 (in Chinese). https://doi.org/10.15951/j.tmgcxb.2004.09.001

Zheng, W. Z., Hou, C. C., \& Chang, W. (2018). Experimental study on mechanical behavior of circular concrete columns confined by high-strength spiral. Journal of Building Structures, 39(6), 21-31 (in Chinese). https://doi.org/10.14006/j.jzjgxb.2018.06.003 